\title{
Temporal Dynamics of East Texas Caddo Sites with 10 or More Radiocarbon Dates
}

Robert Z. Selden Jr. Heritage Research Center, Stephen F. Austin State University

Timothy K. Perttula

Heritage Research Center, Stephen F. Austin State University

Follow this and additional works at: https://scholarworks.sfasu.edu/ita

Part of the American Material Culture Commons, Archaeological Anthropology Commons, Environmental Studies Commons, Other American Studies Commons, Other Arts and Humanities Commons, Other History of Art, Architecture, and Archaeology Commons, and the United States History Commons

Tell us how this article helped you.

This Article is brought to you for free and open access by the Center for Regional Heritage Research at SFA ScholarWorks. It has been accepted for inclusion in Index of Texas Archaeology: Open Access Gray Literature from the Lone Star State by an authorized editor of SFA ScholarWorks. For more information, please contact cdsscholarworks@sfasu.edu. 


\section{Temporal Dynamics of East Texas Caddo Sites with 10 or More Radiocarbon Dates}

\section{Creative Commons License}

\section{(c) (1) (8)}

This work is licensed under a Creative Commons Attribution-NonCommercial 4.0 International License 


\title{
Temporal Dynamics of East Texas Caddo Sites with 10 or More Radiocarbon Dates
}

\author{
Robert Z. Selden, Jr. and Timothy K. Perttula
}

\section{INTRODUCTION}

This article represents supplementary data (see Selden and Perttula 2013) highlighting the specifics of date combination and the subsequent production of summed probability distribution samples for Caddo sites in East Texas. All radiocarbon $\left({ }^{44} \mathrm{C}\right)$ dates employed in this effort were collected from research and cultural resource management (CRM) reports and publications, synthesized, then recalibrated in version 4.1 .7 of OxCal (Bronk Ramsey 2012) using IntCal09 (Reimer et al. 2009) (Perttula and Selden 2011).

The raw sample of Caddo ${ }^{14} \mathrm{C}$ dates $(\mathrm{n}=889$, with a standard deviation of 58 ) exceeds the mimimum number of dates -750 suggested by Michczyńska and Pazdur (2004) and 500 by Williams (2012) - but the combined sample ( $n=407$, with a standard deviation of 53 ) docs not meet the required minimum number of dates necessary to achieve significance. However, the distilled sample of 407 dates reduces probability bias introduced by sites with large numbers of ${ }^{14} \mathrm{C}$ dates, and provides a more accurate representation of the temporal character for sites with $\geq 10{ }^{14} \mathrm{C}$ dates (see also Selden and Perttula 2013).

\section{METHODS}

The date combination (R_Combine) process assumes that if all assays collected at a particular site draw carbon from the same reservoir, then they should have the same underlying $\mathrm{F}^{14} \mathrm{C}$ value and can be combined prior to calibration (Bronk Ramsey 2008). The measurements have Gaussian uncertainty distributions, and $X^{2}$ was used to test the assumption that all ratios are the same to reveal whether compelling evidence exists -at the 95\% confidence level - that dates cannot be related to the same event (Bronk Ramsey 2008). Each site-specific figure provides the summed probability distributions (SPDs), calibrated age range for combined assays, and all dates utilized to inform these results.

Although ${ }^{14} \mathrm{C}$ determinations are most often represented in the form $A \pm E$ where $A$ is the radiocarbon estimate (B.P.) and $E$ represents the standard deviation, the method of date combination can be used to create a new ${ }^{14} \mathrm{C}$ determination from multiple assays, often with the ancillary benefit of a decrease in the standard deviation (Ward and Wilson 1978). To test whether a series of ${ }^{14} \mathrm{C}$ determinations are consistent, the pooled mean is calculated by way of $A_{p}$, where:

$$
A_{p}=\left(\sum_{1}^{n} A_{i} / E_{i}^{2}\right) /\left(\sum_{1}^{n} 1 / E_{i}^{2}\right)
$$

followed by the test statistic, $T$, where

$$
T=\sum_{1}^{n}\left(A_{i}-A_{p}\right)^{2} / E_{\mathrm{i}}^{2}
$$

the latter of which illustrates a chi-square distribution on $n-1$ degrees of freedom under the null hypothesis (see Clark 1975:252; Ward and Wilson 1978:21). 
Provided that the ${ }^{14} \mathrm{C}$ determinations are found not to be significantly different, they can then be combined with the pooled age as $A_{p}$ given by (I), and the variance given by:

$$
V\left(A_{p}\right)=\left(\sum_{1}^{n} 1 / E_{i}^{2}\right)^{-1}
$$

(Ward and Wilson 1978:21), which is a process accessible in OxCal by way of the R_Combine function. Once combined with R_Combine, a new date range, standard deviation, and median age is provided for the combined samples (Figure 1). In this study, the new date range replaces the combined dates and was employed within the revised summed probability distribution, while the new median date was used for statistical analyses (see also Selden 2012, 20I3; Selden and Perttula 2013).

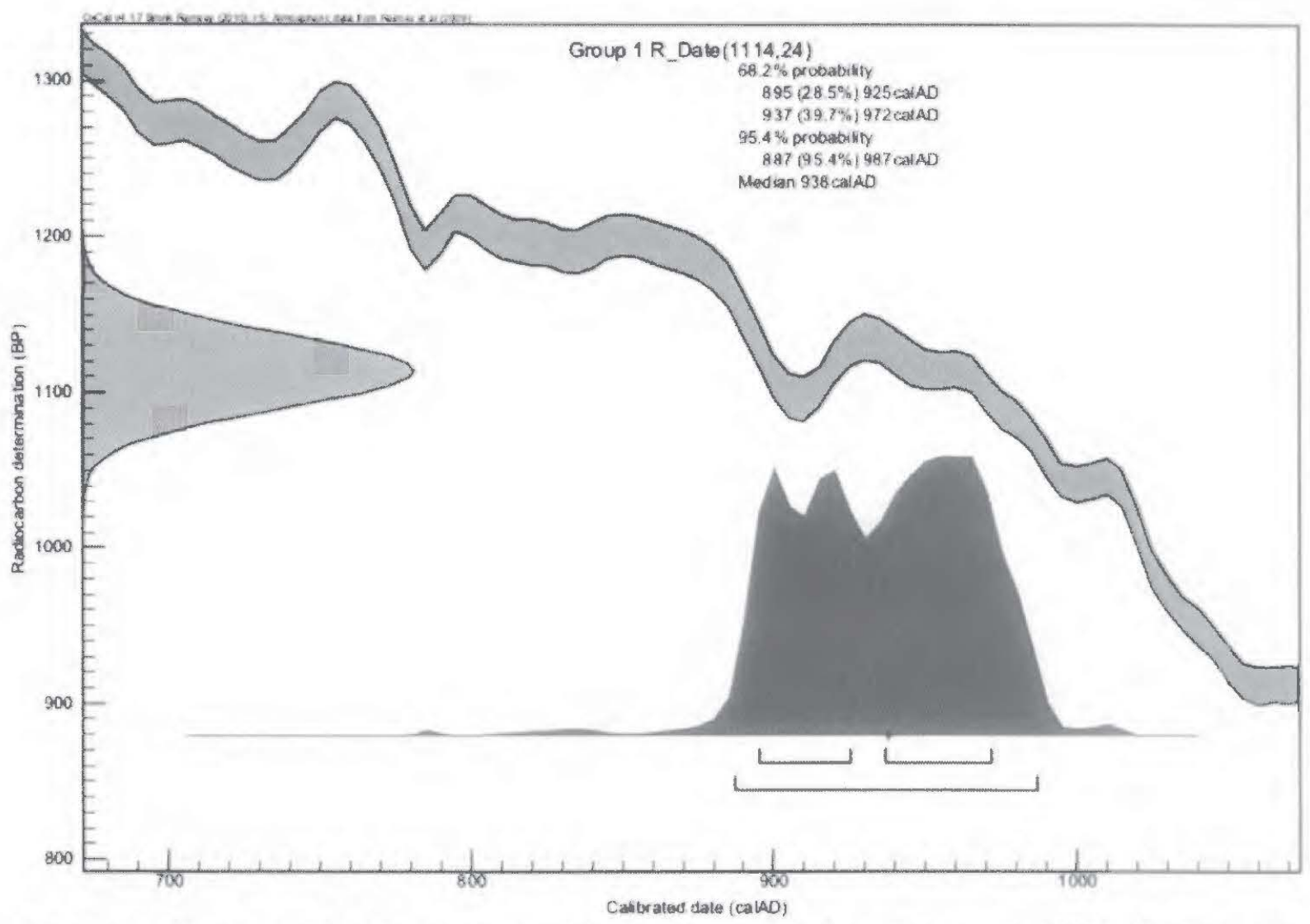

Figure 1. Calibrated results from the R_Combine function for the Lang Pasture site (41AN38), Group 1.

\section{RADIOCARBON CURVE FOR THE ANCESTRAL CADDO TRADITION}

Conventional ${ }^{14} \mathrm{C}$ dates employed in this study were recalibrated using IntCal09 (Figure 2), The radiocarbon curve serves as the basis for date calibration and can aid the process of archaeological interpretation by highlighting temporal zones with reversals and plateaus. Within the span of time of the East Texas Caddo (ca. A.D. 800-1680), the curve has six reversals of varying degrees: ca. A.D. 890-940, A.D. 990-1010, A.D. 1040-1160, A.D. 1180-1210, A.D. 1290-1380, and A.D. 1480-1610. There are also two plateaus within the curve at ca. A.D. 800-870 and A.D. 1220-1260. While this does not produce clues regarding the specific timing of human behaviors, it helps to clarify why some radiocarbon dates have longer spans of probability than others. 


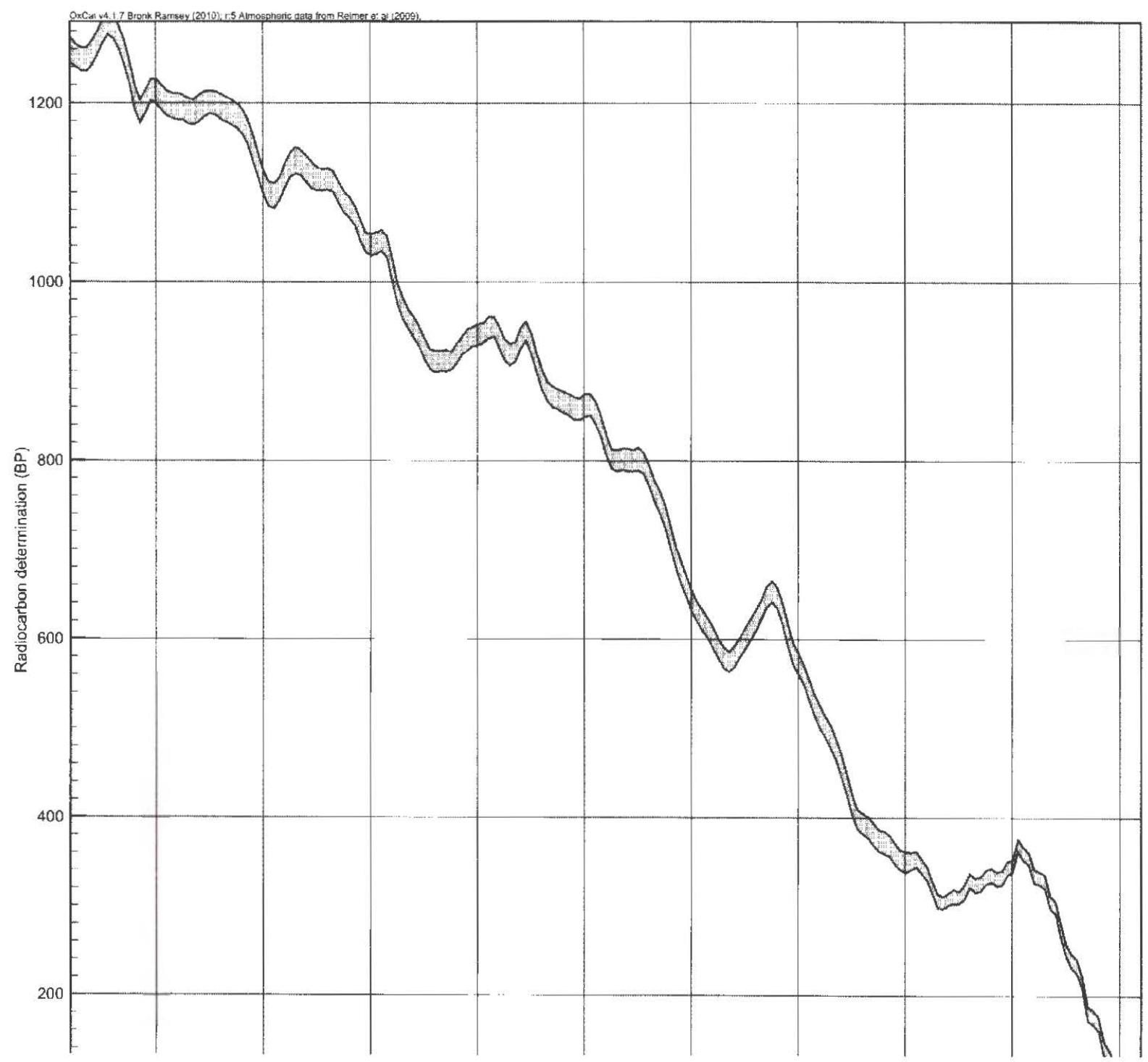

Figure 2. IntCa109 Radiocarbon calibration curve for the ancestral Caddo tradition.

The 1248 corrected dates in the East Texas Radiocarbon Database (ETRD) were calibrated utilizing OxCal 4.1.7 (Bronk Ramsey 2013) and IntCal09 (Reimer et al. 2009). With few exceptions where conventional radiocarbon ages were reported to include older assays found to lack $\delta^{13} \mathrm{C}$ data, value estimates were made for fractionation correction as suggested by Stuiver and Reimer (1993:Table 1): -25\%o for nutshells and charcoal $\left(\mathrm{C}_{3}\right.$ plants), and $-10 \%$ for charred maize $\left(\mathrm{C}_{4}\right.$ plants) (Perttula and Selden 2011).

The Caddo sample was selected from the ETRD on the basis of median age. If the median age fell within the currently accepted temporal construct (ca. A.D. 800-1680) for the Caddo tradition (see Story 1990; Selden and Perttula 2013:Table 1), it was included. Dates not included within this study were those (1) from sites found to lack geographic coordinates, (2) with a standard deviation greater than 200 years, or (3) from non-archaeological contexts (i.e., geoarchaeological profile, backhoe trench, or cutbank not on a site). All remaining dates comprise the foundation of the Caddo sample from East Texas. Data fields imported from the ETRD include site name, trinomial (site number), assay number, raw age, $\delta^{13} \mathrm{C}$, corrected ${ }^{14} \mathrm{C}$ age, 2 sigma calibrated age range, and median age. 
Within the distribution of Caddo ${ }^{14} \mathrm{C}$ assays $(\mathrm{n}=889)$ from the ETRD, there are 117 sites that have from one to five ${ }^{14} \mathrm{C}$ samples, 17 sites with 6-10 samples, seven sites with $11-20$ sites, four sites with $21-30$ samples, two sites with 31-40 samples, one site with 41-50 samples, and two sites with 91-110 samples. The assays from the 19 sites with $\geq 10{ }^{14} \mathrm{C}$ dates were combined via OxCal for two reasons: (1) to reduce the standard deviation and increase the accuracy of each site's temporal assignments and (2) to reduce sampling bias created by the number of samples during statistical analyses.

Once combined, a summed probability distribution (SPD) was produced for each of the 19 sites to illustrate the position of each within the Caddo ancestral tradition. The dates were plotted in a manner where the SPDs, the combined groups, and the individual assays that inform them can be viewed together. These efforts permit the uncombined SPD for each site to be contrasted with the combined SPD and the combined groups that comprise it. This comparison demonstrates the impact that each site has upon the whole of the Caddo sample, and allows for a discussion of regional trends within the temporal sample.

\section{COMBINING THE SAMPLE}

Caddo sites with $\geq 10{ }^{14} \mathrm{C}$ dates include Lang Pasture (41AN38), George C. Davis (41CE19), Kitchen Branch (41CP220), Pilgrim's Pride (41CP304), Hickory Hill (41CP408), Spider Knoll (41DT11), Arnold (41HP102), Hurricane Hill (41HP106), Peerless Bottoms (41HP175), Pine Tree Mound (41HS15), Tallow Grove (41NA23I), Beech Ridge (41NA242), Nawi haia ina (41RK170), Oak Hill Village (41RK214), Ear Spool (41TT653), George E. Richey (41TT851), William A. Ford (41TT852), James E. Richey (41TT853), and Rookery Ridge (4IUR133). Below, the ${ }^{14} \mathrm{C}$ assays from these 19 sites are refined through date combination, and the subsequent results (combined dates) replace the original assays within the analysis of all Caddo dates. Radiocarbon samples from these sites were refined through date combination in an effort to (1) decrease the bias and standard deviation of the Caddo sample prior to statistical analysis, and (2) to create accurate site and period-specific summed probability distributions.

\section{Lang Pasture (41AN38)}

The Caddo period ${ }^{14} \mathrm{C}$ dates from the Lang Pasture site $(\mathrm{n}=23)$ were combined into four groups (Figure 3). Group 1 consists of Beta-236845, Beta-236774, and Beta-236779. Group 2 consists of Beta-236784 and Beta-236789. Group 3 consists of Beta-236772, Beta-236775, Beta-236777, Beta-236783, Beta-236793, Beta-239846, Beta-236785, Beta-236786, Beta-236781, Beta-239850, Beta-236782, and Beta-236780. Group 4 consists of Beta-236773, Beta-236792, and Beta-236776. Those dates from the site that are unable to be combined are Beta-236788 and Beta-239847 (Perttula and Selden 2011).

\section{George C. Davis (4ICE19)}

The Caddo period ${ }^{14} \mathrm{C}$ dates from the George C. Davis site $(n=115)$ were combined into three groups (Figure 4). Group 1 consists of Tx-919, Tx-1223, Tx-4624, Tx-4195, Tx-1294, Tx-1295, Tx-908, Tx-4189, Tx-4188, Tx-8309, Tx-1212, Tx-913, Tx-920, Tx-925, Tx-3307, Tx-1399, Tx-676, Tx-1204, Tx-1222, Tx-1227, Tx-3694, Tx-1202, Tx-922, Tx-1208, Tx-677, Tx-1308, Tx-914b, Tx-914a, Tx-1398, Tx-3270, Tx-1307, Tx-4194, Tx-4198, Tx-4201, Tx-923, Tx-4196, Tx-3400, Tx-4623, Tx-1217, Tx-675, Tx-1206, Tx-1221, Tx-926, Tx-3399, and Tx-4187. Group 2 consists of Tx-917, Tx-1224, Tx-4186, Tx-906a, Tx-907, Tx-3692, Tx-3273, Tx-1213, Tx-921, Tx-924, Tx-1310, Tx-4193, Tx-4622, Tx-1201, Tx-1168, Tx-3275, Tx-1203, Tx-1315, Tx-916, Tx-1210, Tx-1397, Tx-1311, Tx-3310, Tx-4618, Tx-912, Tx-4192, Tx-1209, Tx-1211, Tx-905, Tx-1215, Tx-1313, Tx-1228, Tx-4199, Tx-1405, Tx-1395, Tx-910, Tx-915, Tx-3267, Tx-3697, Tx-3272, Tx-3276, Tx-918, Tx-1316, Tx-1214, Tx-4190, Tx-4340, Tx-3401, Tx-3271, Tx-1216, Tx-4616, Tx-1231, Tx-1317, Tx-4197, Tx-1312, Tx-4185, Tx-1318, Tx-3269, Tx-1320, Tx-1396, Tx-3274, Tx-1226, Tx-1314, and Tx-1319. Group 3 consists of Tx-3308 and Tx-1207. 


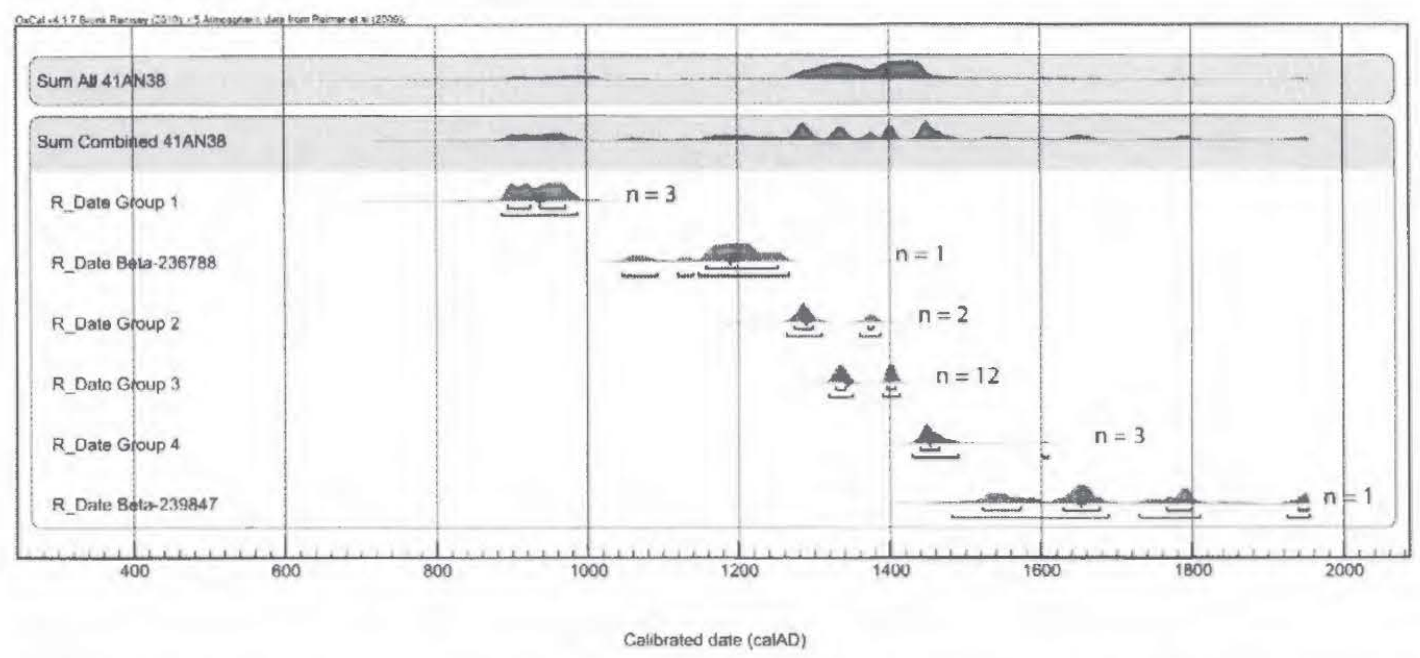

Figure 3. All and combined summed probability distributions for Caddo period dates from the Lang Pasture site (4lAN38) with $1 \sigma$ and $2 \sigma$ ranges, median ages, and number of samples.

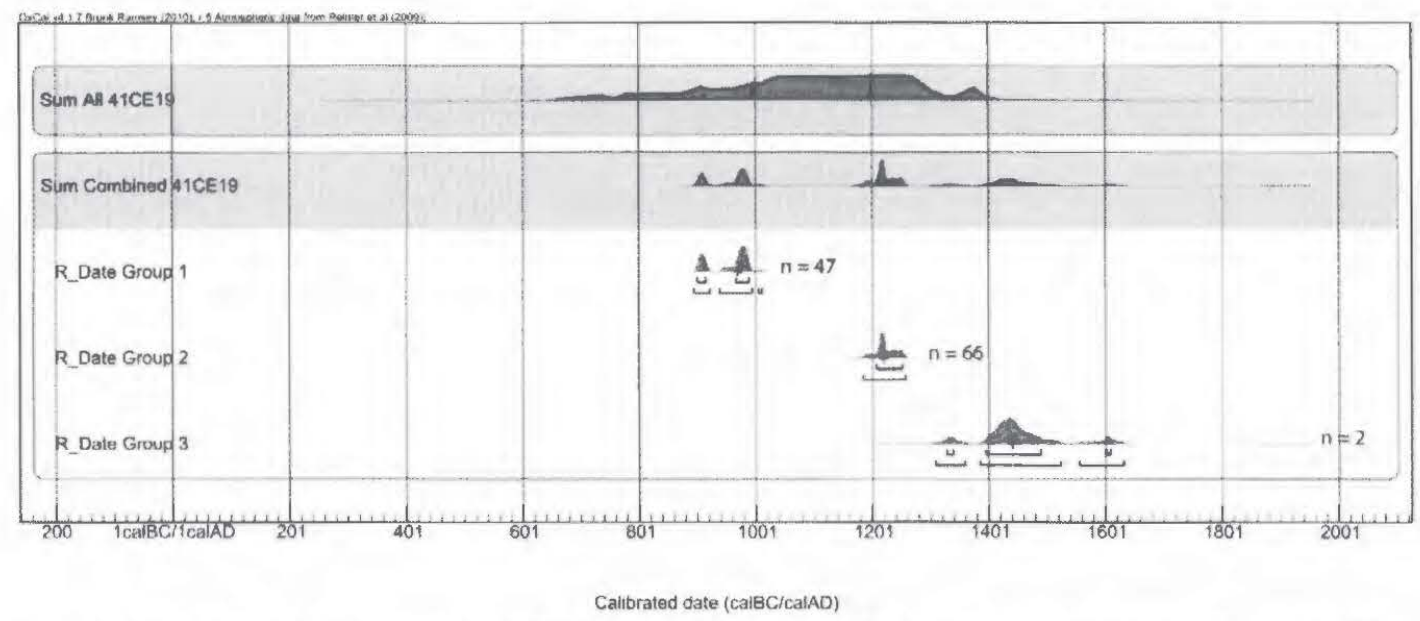

Figure 4. All and combined summed probability distributions for Caddo period dates from the George C. Davis site (41CE19) with $1 \sigma$ and $2 \sigma$ ranges, median ages, and number of samples.

\section{Kitchen Branch (41CP220)}

The Caddo period ${ }^{14} \mathrm{C}$ dates from the Kitchen Branch site $(n=18)$ were combined into four groups (Figure 5). Group 1 consists of Beta-322672, Beta-319968, and Beta-319972. Group 2 consists of Beta-319974 and Beta-322666. Group 3 consists of Beta-322668, Beta-322669, Beta-322671, and Beta-322673. Group 4 consists of Beta-204251, Beta-319967, Beta-322665, Beta-204250, Beta-319973, and Beta-319969. Those dates unable to be combined include Beta-322667, and Beta-319977.

\section{Pilgrim's Pride (41CP304)}

The Caddo period ${ }^{14} \mathrm{C}$ dates from the Pilgrim's Pride site $(n=29)$ could be combined into two groups (Figure 6). Group 1 consists of Beta-138865, Beta-138860, Beta-138854, Beta-138864, Beta-138866, Beta-138858, Beta-133239, Beta-138853, Beta-138852, Beta-138850, and Beta-138856. Group 2 consists of Beta-132239, Beta-138857, Beta-125987, Beta-132240, Beta-133240, Beta-132243, Beta-138863, Beta138862, Beta-125985, Beta-138867, Beta-138859, Beta-138851, Beta-125986, Beta-132242, Beta-138855, Beta-132244, Beta-132241, and Beta-132245. 


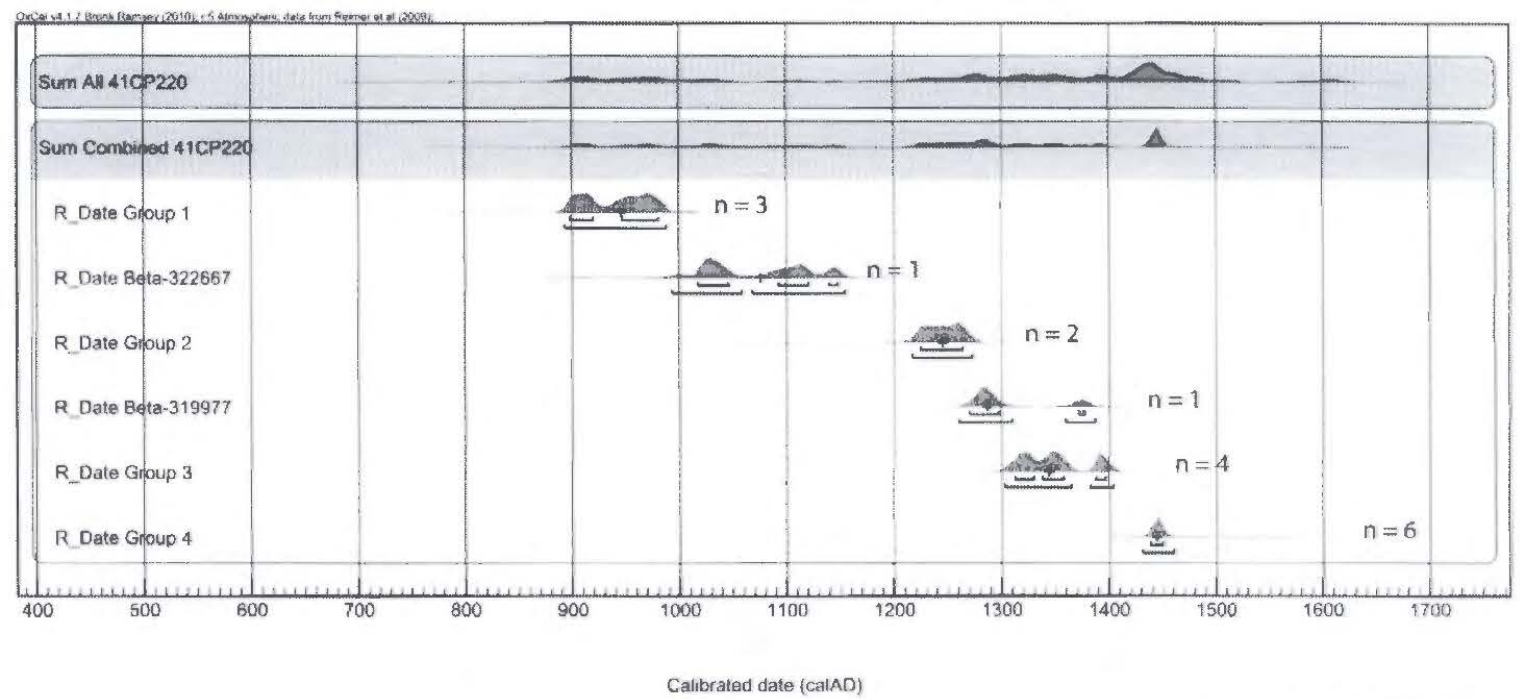

Figure 5. All and combined summed probability distributions for Caddo period dates from the Kitchen Branch site $(41 \mathrm{CP} 220)$ with $1 \sigma$ and $2 \sigma$ ranges, median ages, and number of samples.

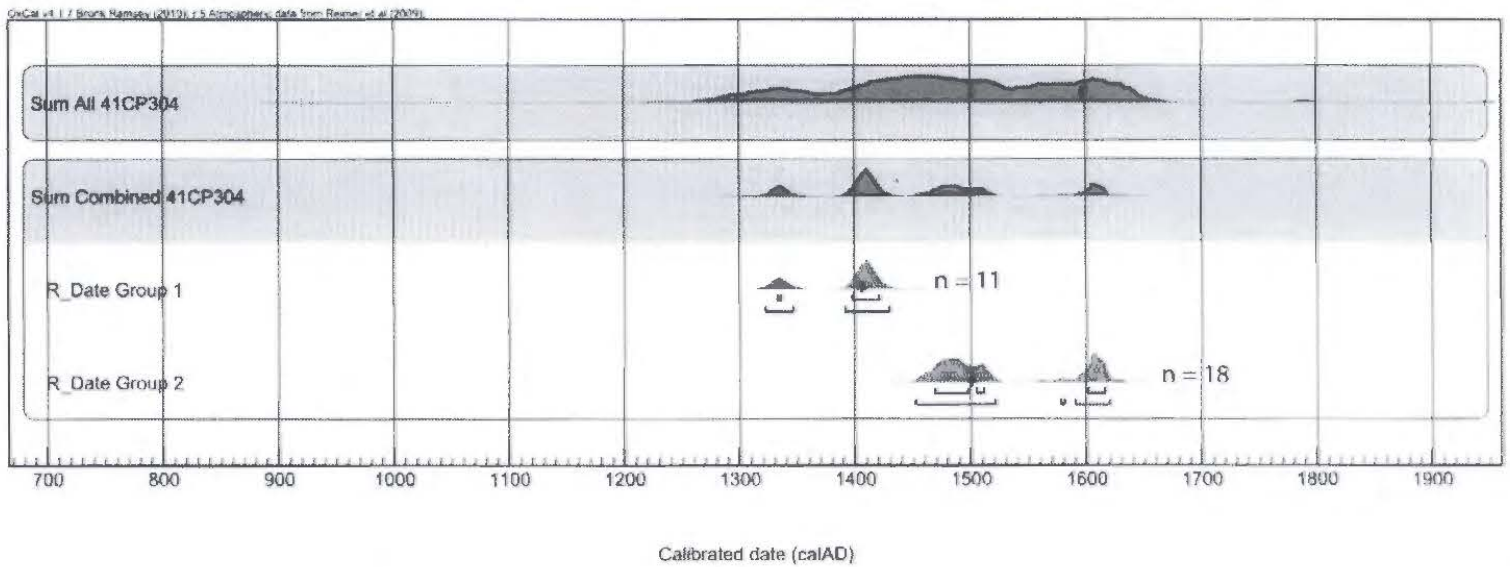

Figure 6. All and combined summed probability distributions for Caddo period dates from the Pilgrim's Pride site (41CP304) with $1 \sigma$ and $2 \sigma$ ranges, median ages, and number of samples.

\section{Hickory Hill (4ICP408)}

The Caddo period ${ }^{14} \mathrm{C}$ dates from the Hickory Hill site $(\mathrm{n}=27)$ were combined into three groups (Figure 7). Group 1 consists of Beta-184990, Beta-184993, Beta-184991, Beta-314351, Beta-313934, Beta-313936, Beta-313931, and Beta-184992. Group 2 consists of Beta-313950, Beta-184994, Beta-313933, Beta-313949, Beta-313939, Beta-313937, Beta-313947, Beta-313349, Beta-313951, Beta-313942, Beta-313953, Beta313940, Beta-313948, and Beta-313941. Group 3 includes Beta-313945, Beta-313952, Beta-313944, and Beta-313946. Only one date (Beta-313943) was unable to be combined.

\section{Spider Knoll (41DT11)}

The Caddo period ${ }^{14} \mathrm{C}$ dates from the Spider Knoll site $(\mathrm{n}=22)$ could be combined into two groups (Figure 8). Group 1 consists of Beta-48769, Beta-65799, Beta-65796, Beta-65803, Beta-65798, Beta-48768, Beta-46858, Beta-63301, Beta-63305, Beta-46860, Beta-63297, Beta-63303, Beta-63300, Beta-63302, Beta-65802, and Beta-65801. Group 2 includes Beta-65804, Beta-63304, Beta-46859, Beta-65797, Beta63299, and Beta-63298. 


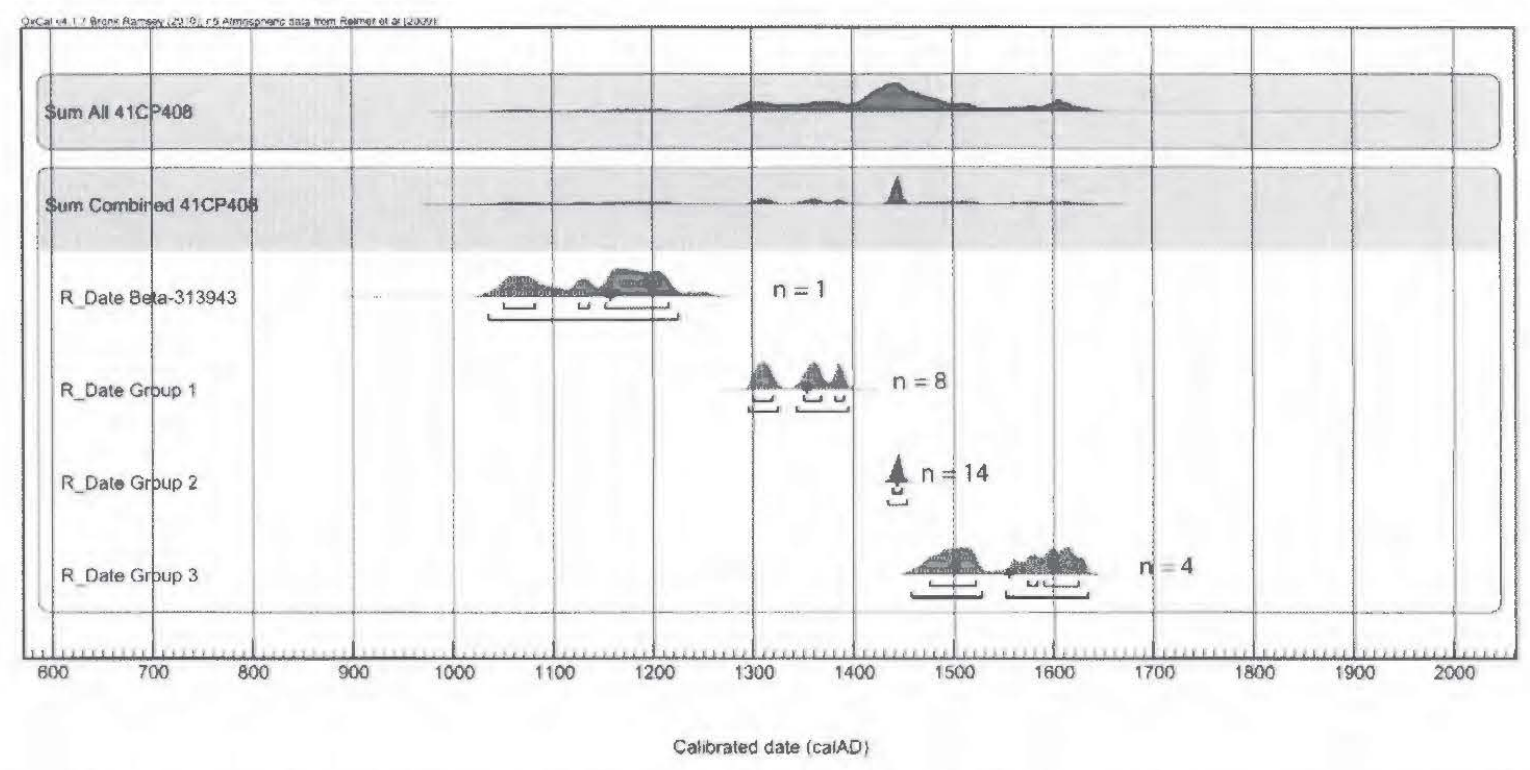

Figure 7. All and combined summed probability distributions for Caddo period dates from the Hickory Hill site $(41 \mathrm{CP} 408)$ with $1 \sigma$ and $2 \sigma$ ranges, median ages, and number of samples.

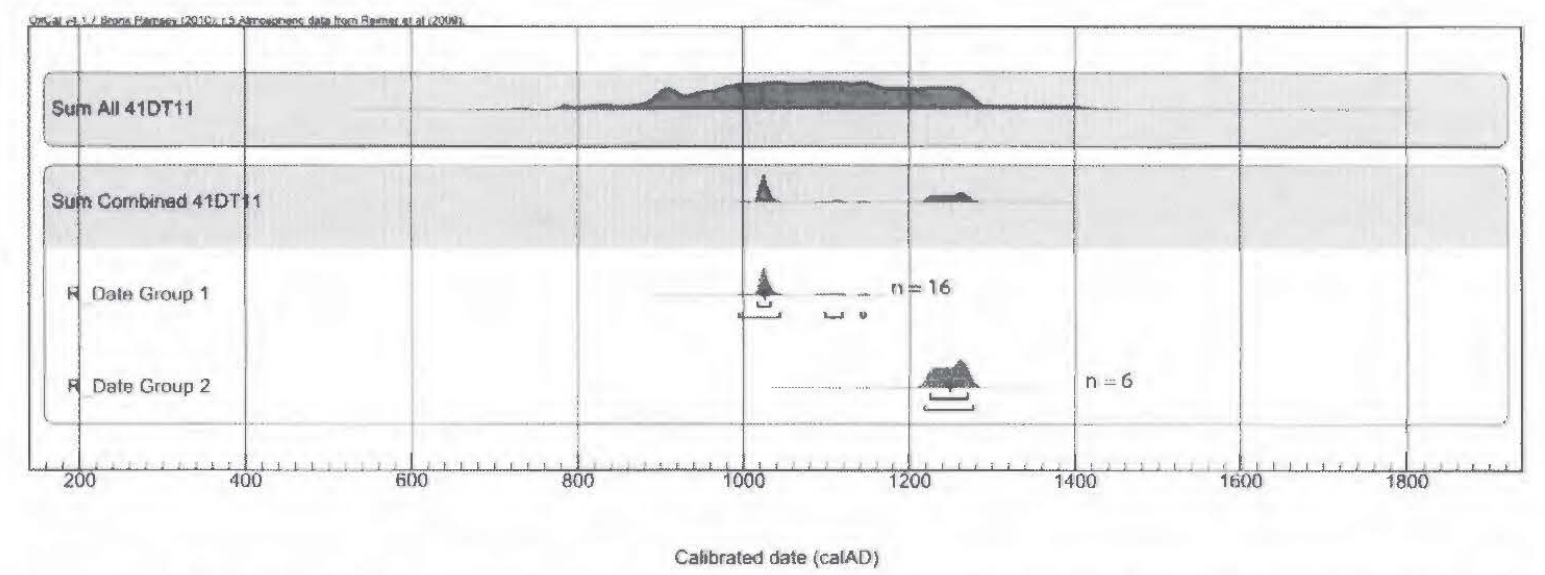

Figure 8. All and combined summed probability distributions for Caddo period dates from the Spider Knoll site (41DT11) with $1 \sigma$ and $2 \sigma$ ranges, median ages, and number of samples.

\section{Arnold (41HP102)}

The Caddo period ${ }^{14} \mathrm{C}$ dates from the Arnold site $(\mathrm{n}=11)$ were combined into one group (Figure 9). Group 1 consists of SMU-346, Tx-2043, Tx-2041, SMU-316, SMU-325, SMU-310, SMU-341, SMU-328, Tx-2048, and Tx-2044. A single, and much later, radiocarbon date (Tx-2049) was unable to be combined.

\section{Hurricane Hill (4IHPI06)}

The Caddo period ${ }^{14} \mathrm{C}$ dates from the Hurricane Hill site $(\mathrm{n}=11)$ could be combined into three groups (Figure 10). Group 1 consists of Beta-82918, Beta-82911, Beta-82922, and Beta-82916. Group 2 consists of Beta-82921, Beta-108169, Beta-82912, and Beta-82920. Group 3 includes Beta-82909, Beta-82919, and Beta-82910. 


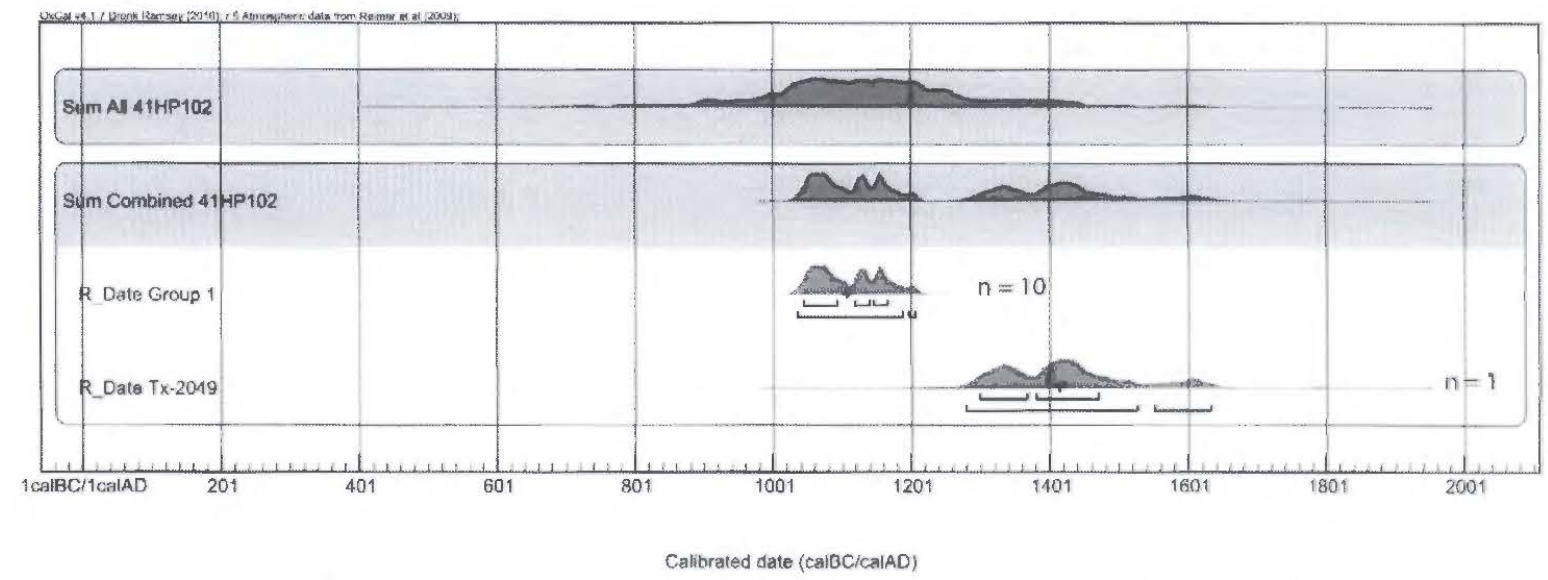

Figure 9. All and combined summed probability distributions for Caddo period dates from the Arnold site (41HP102) with $1 \sigma$ and $2 \sigma$ ranges, median ages, and number of samples.

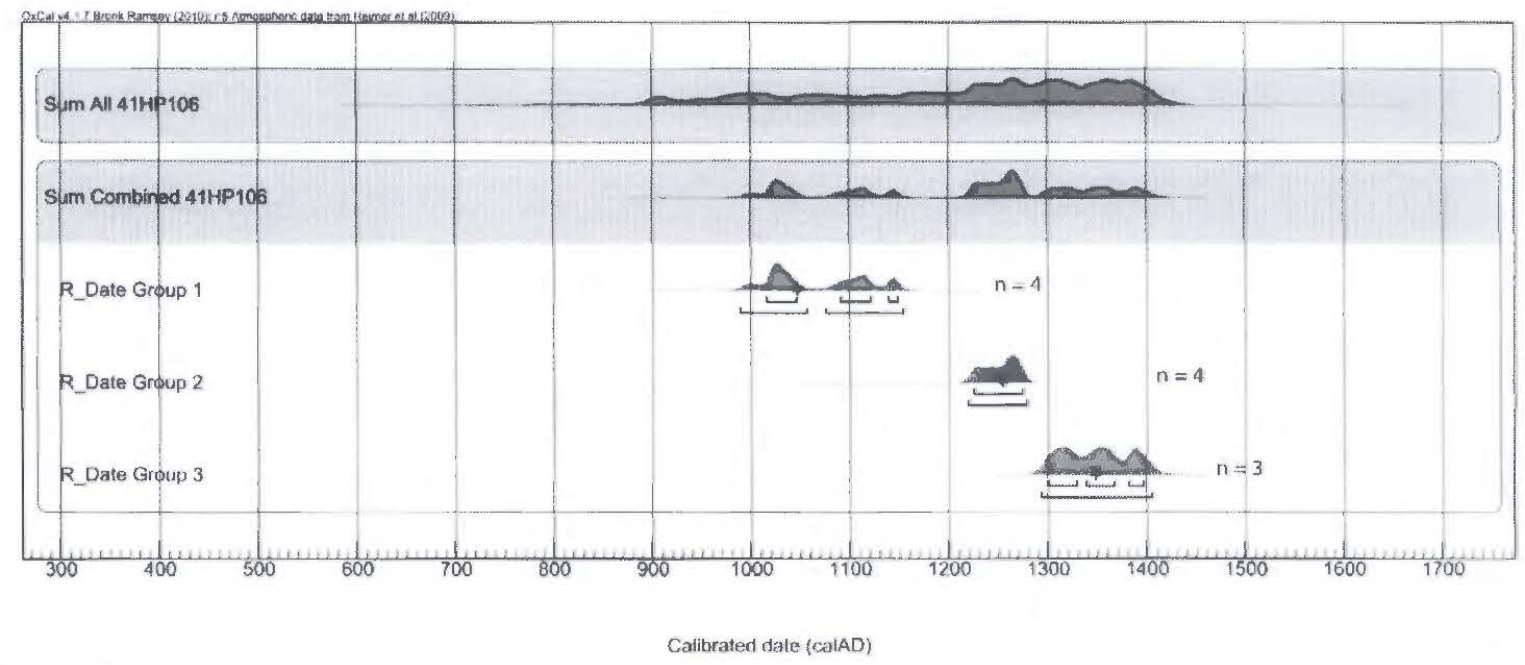

Figure 10. All and combined summed probability distributions for Caddo period dates from the Hurricane Hill site (41HP106) with $1 \sigma$ and $2 \sigma$ ranges, median ages, and number of samples.

\section{Peerless Bottoms (41HP175)}

The Caddo period ${ }^{14} \mathrm{C}$ dates from the Peerless Bottoms site $(\mathrm{n}=11)$ were able to be combined into two groups (Figure 11). Group 1 consists of Beta-81385, Beta-51382, and Beta-52246. Group 2 consists of Beta-51387, Beta-51388, Beta-51390, Beta-51386, Beta-51392, Beta-51383, Beta-51391, and Beta-51389.

\section{Pine Tree Mound (41HS15)}

The Caddo period ${ }^{14} \mathrm{C}$ dates from the Pine Tree Mound site $(\mathrm{n}=93)$ were combined into four groups (Figure 12). Group 1 consists of only two radiocarbon samples, Beta-242055 and Beta-217072. Group 2 consists of Beta-242053, Beta-260409, Beta-260404, Beta-260407, Beta-217066, Beta-217071, Beta-260414, Beta-217081, Beta-217073, Beta-260354, Beta-260380, Beta-260396, Beta-260411, Beta-217062, Beta243451, Beta-243453, Beta-242057, and Beta-260381. Group 3 consists of Beta-260399, Beta-217056, Beta-217063, Beta-217080, Beta-217067, Beta-217074, Beta-260386, Beta-260366, Beta-260415, Beta217057, Beta-217058, Beta-242051, Beta-242056, Beta-260385, Beta-217076, Beta-260355, Beta-260360, 


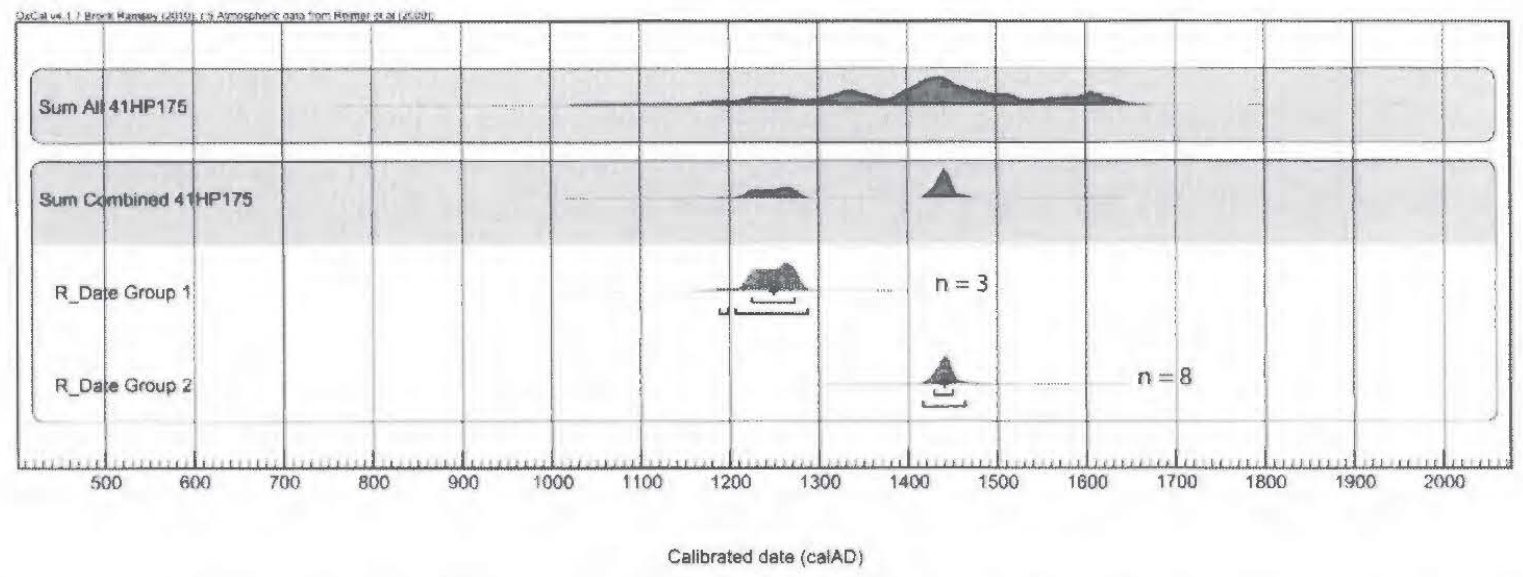

Figure 11. All and combined summed probability distributions for Caddo period dates from the Peerless Bottoms site (41HP175) with $1 \sigma$ and $2 \sigma$ ranges, median ages, and number of samples.

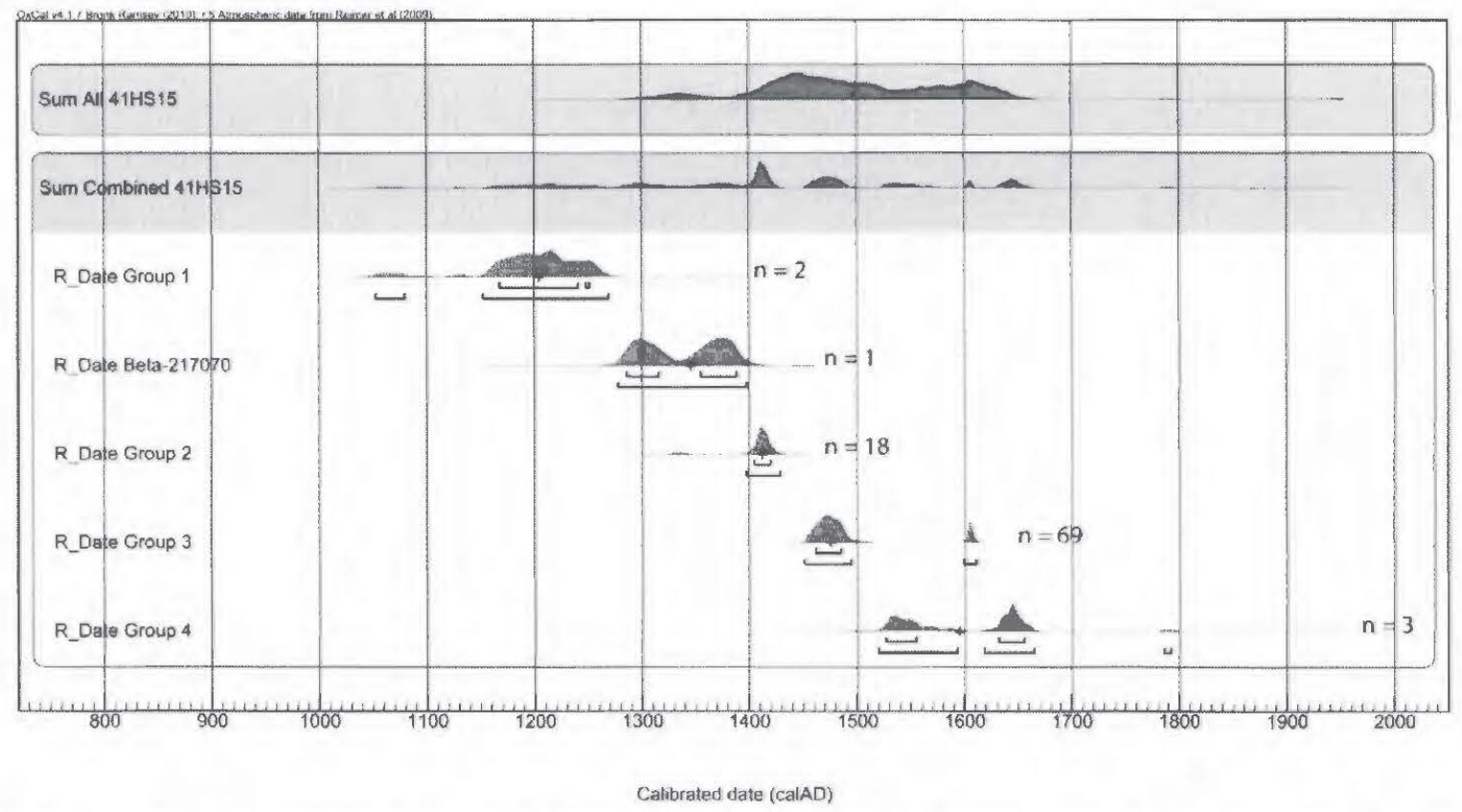

Figure 12. All and combined summed probability distributions for Caddo period dates from the Pine Tree Mound site (41HS15) with $1 \sigma$ and $2 \sigma$ ranges, median ages, and number of samples.

Beta-260367, Beta-160370, Beta-260410, Beta-217079, Beta-260368, Beta-260378, Beta-260402, Beta260403, Beta-260363, Beta-260364, Beta-260412, Beta-264967, Beta-217064, Beta-243452, Beta-260405, Beta-217069, Beta-217060, Beta-217061, Beta-242052, Beta-260356, Beta-260362, Beta-217075, Beta260395, Beta-217065, Beta-217068, Beta-242050, Beta-260376, Beta-260390, Beta-260400, Beta-264966, Beta-260388, Beta-260406, Beta-242054, Beta-260365, Beta-260377, Beta-260389, Beta-260398, Beta217077, Beta-242047, Beta-260391, Beta-243450, Beta-260373, Beta-260375, Beta-260361, Beta-260397, Beta-260401, Beta-217059, Beta-217078, Beta-260384, Beta-260408, Beta-260413, and Beta-260353. Group 4 includes Beta-260369, Beta-260393, and Beta-260383. There is a single date (Beta-217070) that could not be combined. 


\section{Tallow Grove (41NA231)}

The Caddo period ${ }^{14} \mathrm{C}$ dates from the Tallow Grove site $(\mathrm{n}=15)$ could be combined into three groups (Figure 13). Group 1 consists of Beta-203659 and Beta-203662. Group 2 consists of Beta-193127, Beta203657, Beta-187338, Beta-201985, Beta-193125, Beta-193128, and Beta-203661, while Group 3 includes Beta-203658, Beta-193129, Beta-193126, Beta-203660, Beta-204777, and Beta-204776.

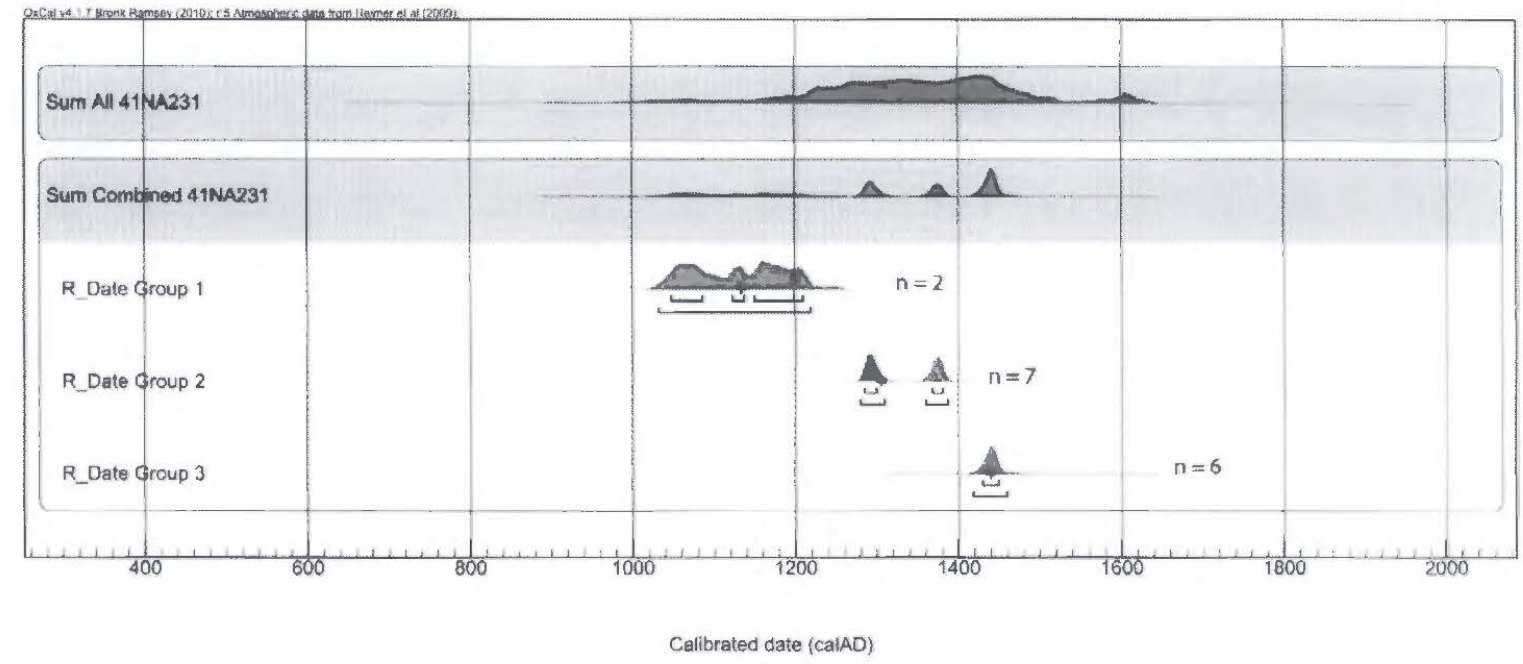

Figure 13. All and combined summed probability distributions for Caddo period dates from the Tallow Grove site (41NA231) with $1 \sigma$ and $2 \sigma$ ranges, median ages, and number of samples.

\section{Beech Ridge (41NA242)}

The Caddo period ${ }^{14} \mathrm{C}$ dates from the Beech Ridge site $(\mathrm{n}=10)$ were combined into one group (Figure 14). Group 1 consists of Beta-187339, Beta-201988, Beta-193133, Beta-193132, Beta-201987, Beta-203671, Beta-198018, Beta-203670, and Beta-193130. A single, and later, radiocarbon date (Beta-193131) was unable to be combined.

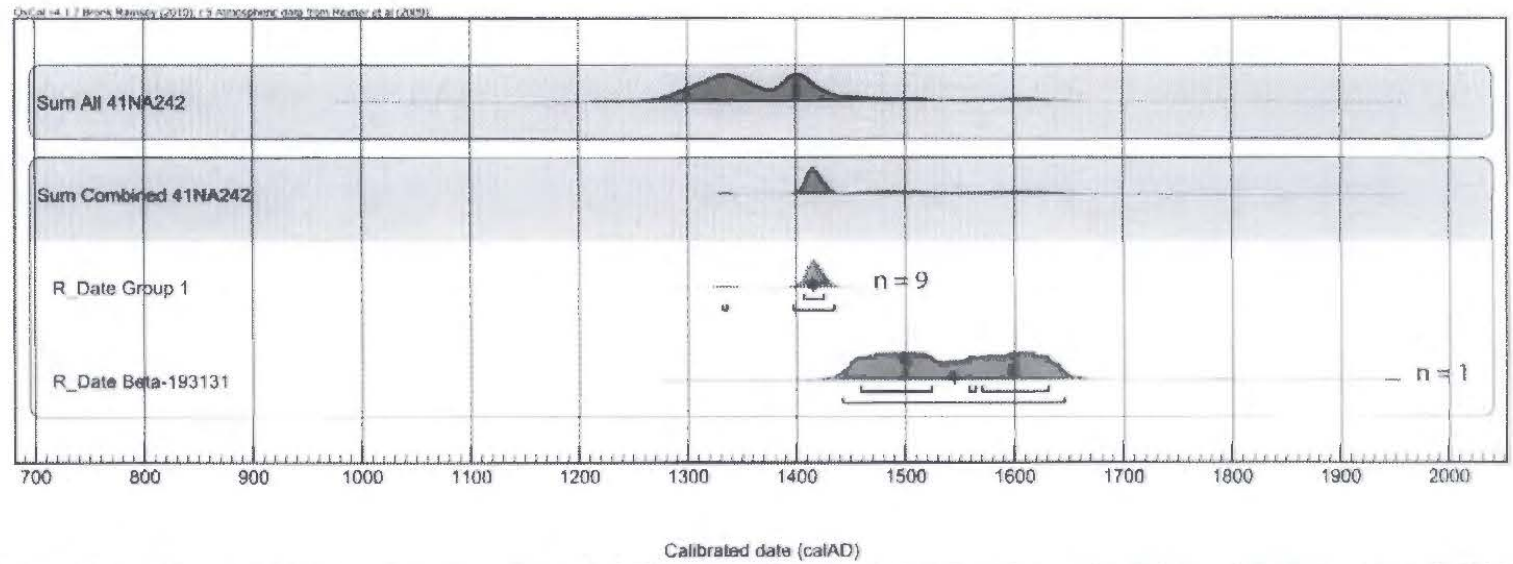

Figure 14. All and combined summed probability distributions for Caddo period dates from the Beech Ridge site (41NA242) with $1 \sigma$ and $2 \sigma$ ranges, median ages, and number of samples.

\section{Nawi haia ina (41RK170)}

The Caddo period ${ }^{14} \mathrm{C}$ dates from the Nawi haia ina site $(\mathrm{n}=11)$ were able to be combined into two groups (Figure 15). Group 1 consists of Beta-166770, Beta-166764, Beta-166765, Beta-166762, Beta-166769, and 
Beta-166768. Group 2 consists of Beta-166763, Beta-166766, and Beta-164353. Beta-166767 and Beta164352 radiocarbon dates were unable to be combined with the other two groups.

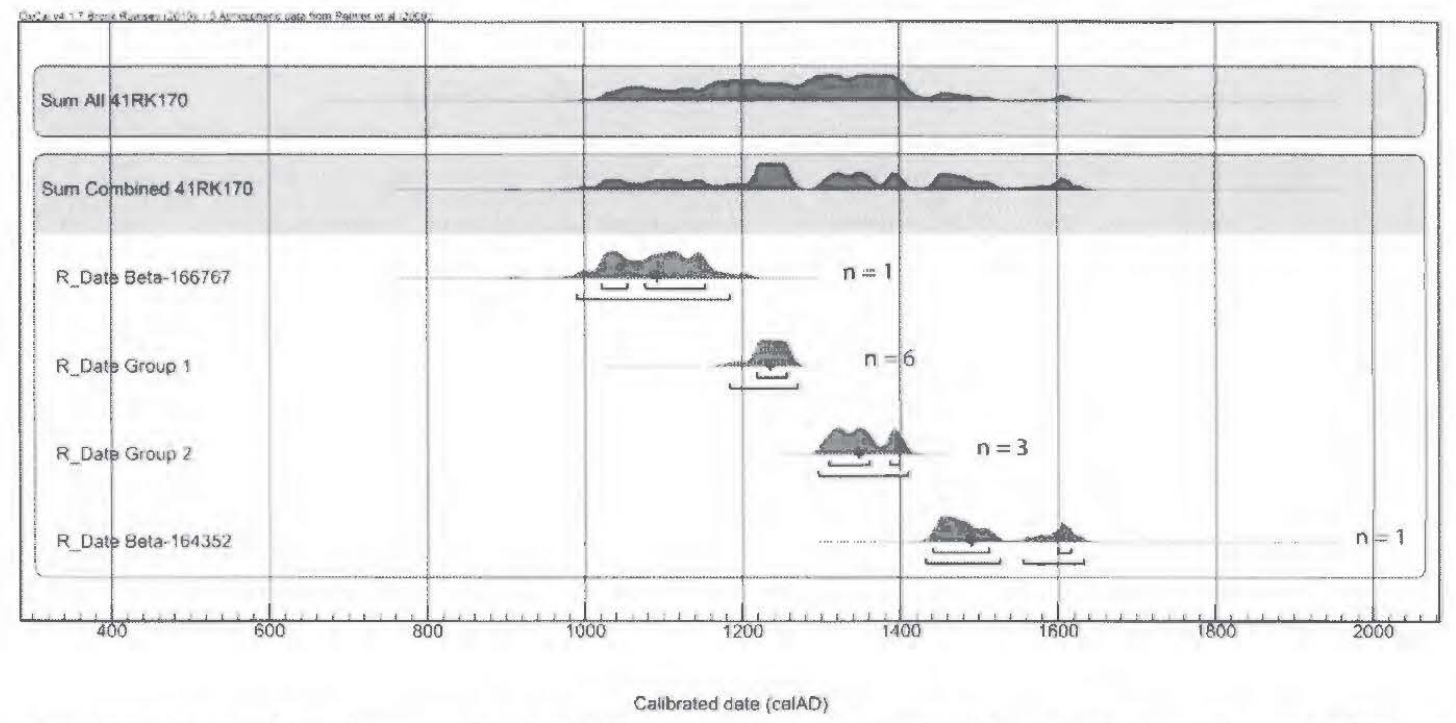

Figure 15. All and combined summed probability distributions for Caddo period dates from the Nawi haia ina site $(41 \mathrm{RK} 170)$ with $I \sigma$ and $2 \sigma$ ranges, median ages, and number of samples.

\section{Oak Hill Village (41RK214)}

The Caddo period ${ }^{14} \mathrm{C}$ dates from the Oak Hill Village site $(n=32)$ were combined into two groups (Figure 16). Group 1 consists of Beta-110063, Beta-81681, Beta-96913, Beta-73939, Beta-81486, Beta-71486, Beta96918, Beta-96920, Beta-96914, Beta-96919, Beta-96911, and Beta-96910. Group 2 includes Beta-96909, Beta-96912, Beta-96908, Beta-96916, Beta-60088, Beta-11062, Beta-110061, Beta-96915, Beta-110065, Beta-96921, Beta-73940, Beta-110064, Beta-110066, Beta-110067, Beta-110068, Beta-73936, Beta-73941, and Beta-107399. There are two dates (Beta-107401 and Beta-107400) that were unable to be combined.

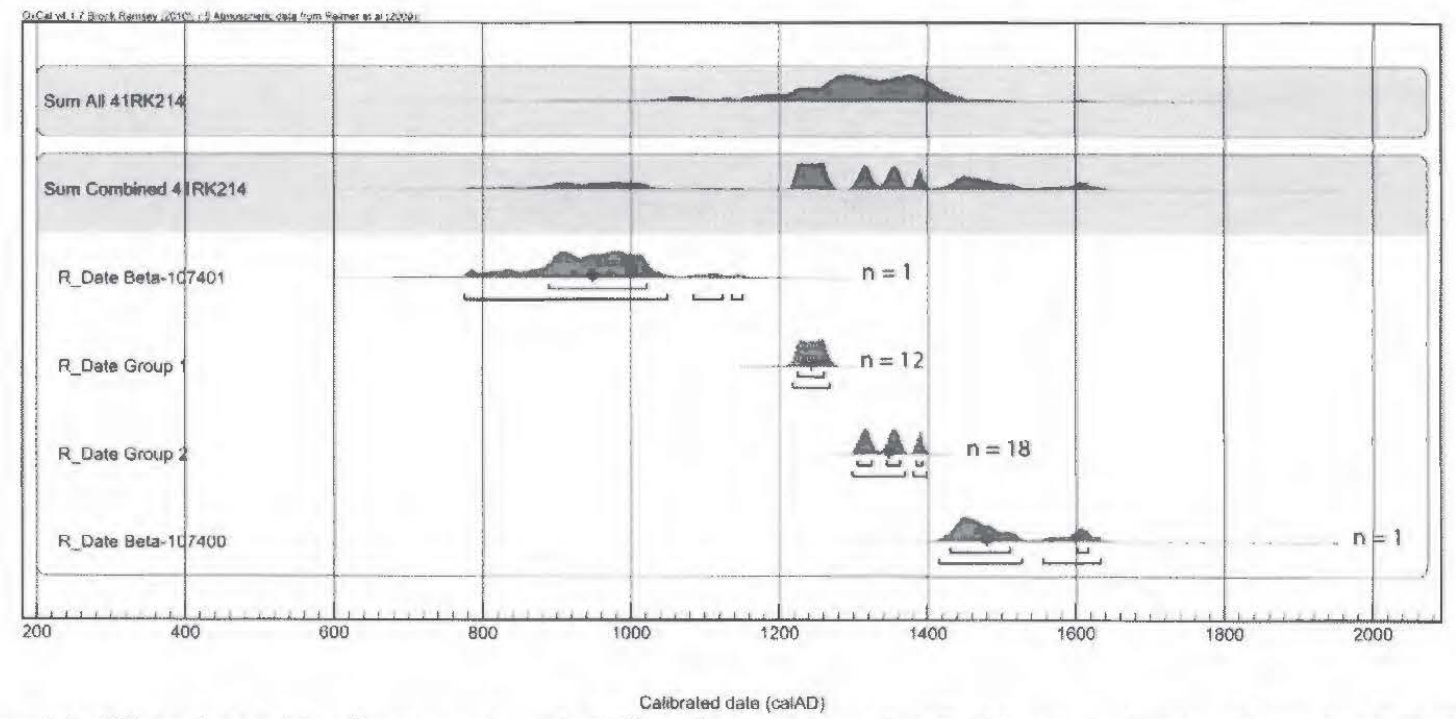

Figure 16. All and combined summed probability distributions for Caddo period dates from the Oak Hill Village site (41RK214) with $1 \sigma$ and $2 \sigma$ ranges, median ages, and number of samples. 


\section{Ear Spool (4ITT653)}

The Caddo period ${ }^{14} \mathrm{C}$ dates from the Ear Spool site ( $\mathrm{n}=17$ ) were combined into two groups (Figure 17). Group 1 consists of Beta-117274, Beta-117270, and Beta-119005. Group 2 consists of Beta-117271, Beta119001, Beta-119006, Beta-229319, Beta-117275, Beta-105531, Beta-105530, Beta-119652, Beta-119623, Beta-119002, Beta-119003, Beta-117273, Beta-229322, and Beta-119264.

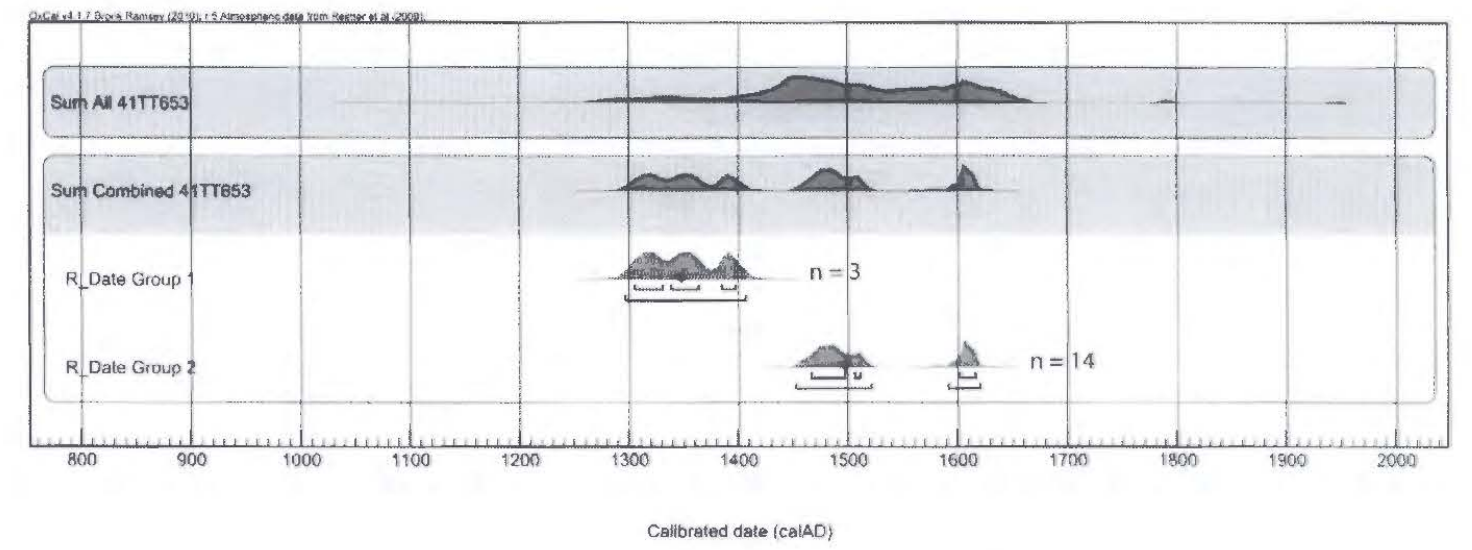

Figure 17. All and combined summed probability distributions for Caddo period dates from the Ear Spool site (41TT653) with $1 \sigma$ and 20 ranges, median ages, and number of samples.

\section{George E. Richey (4ITT85I)}

The Caddo period ${ }^{14} \mathrm{C}$ dates from the George E. Richey site $(n=44)$ could be combined into six groups (Figure 18). Group 1 consists of Beta-300054 and Beta-305077. Group 2 consists of Beta-300036, Beta300034, Beta-300039, and Beta-300027. Group 3 consists of Beta-300023, Beta-300050, Beta-300038, Beta-305059, Beta-300045, Beta-300029, Beta-300049, Beta-242374, Beta-300026, Beta-300033, Beta300046, Beta-300040, Beta-305063, Beta-300052, Beta-242375, and Beta-300031. Group 4 consists of Beta-300024, Beta-300041, Beta-242377, Beta-300043, Beta-300067, Beta-305064, Beta-305081, Beta242376, Beta-300028, Beta-305078, Beta-305062, and Beta-300032.Group 5 consists of Beta-300053, Beta-300047, Beta-305082, Beta-305070, Beta-305079, and Beta-300030. Group 6 includes Beta-300044, Beta-300048, and Beta-300035. One date (Beta-305076) was unable to be combined with the defined six groups of radiocarbon dates.

\section{William A. Ford (4ITT852)}

The Caddo period ${ }^{14} \mathrm{C}$ dates from the William A. Ford site $(n=38)$ were combined into three groups (Figure 19). Group 1 consists of Beta-300074, Beta-300094, Beta-300092, Beta-300090, Beta-305098, Beta300103, Beta-300075, Beta-300059, Beta-300082, Beta-300069, Beta-300096, Beta-300089, Beta-300078, and Beta-305095. Group 2 consists of Beta-300067, Beta-300084, Beta-300068, Beta-300072, Beta-300079, Beta-300087, Beta-300081, Beta-300083, Beta-242381, and Beta-242378. Group 3 includes Beta-300073, Beta-300105, Beta-242380, Beta-300098, Beta-300095, Beta-300080, Beta-305103, Beta-300099, Beta300056, Beta-300106, Beta-300100, and Beta-300088. Two dates (Beta-300101 and Beta-242379) were unable to be combined. 


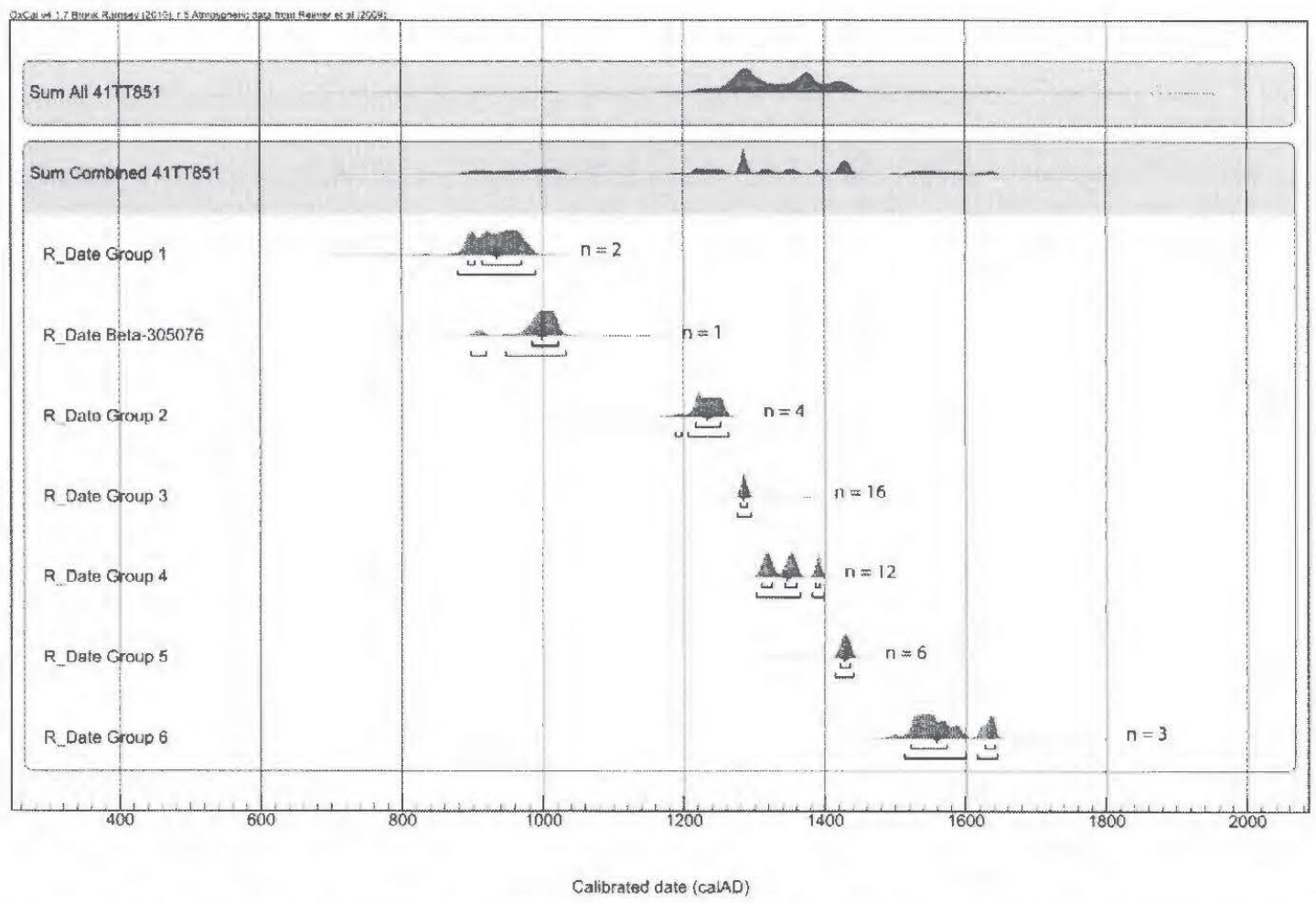

Figure 18. All and combined summed probability distributions for Caddo period dates from the George E. Richey site (41TT851) with $1 \sigma$ and $2 \sigma$ ranges, median ages, and number of samples.

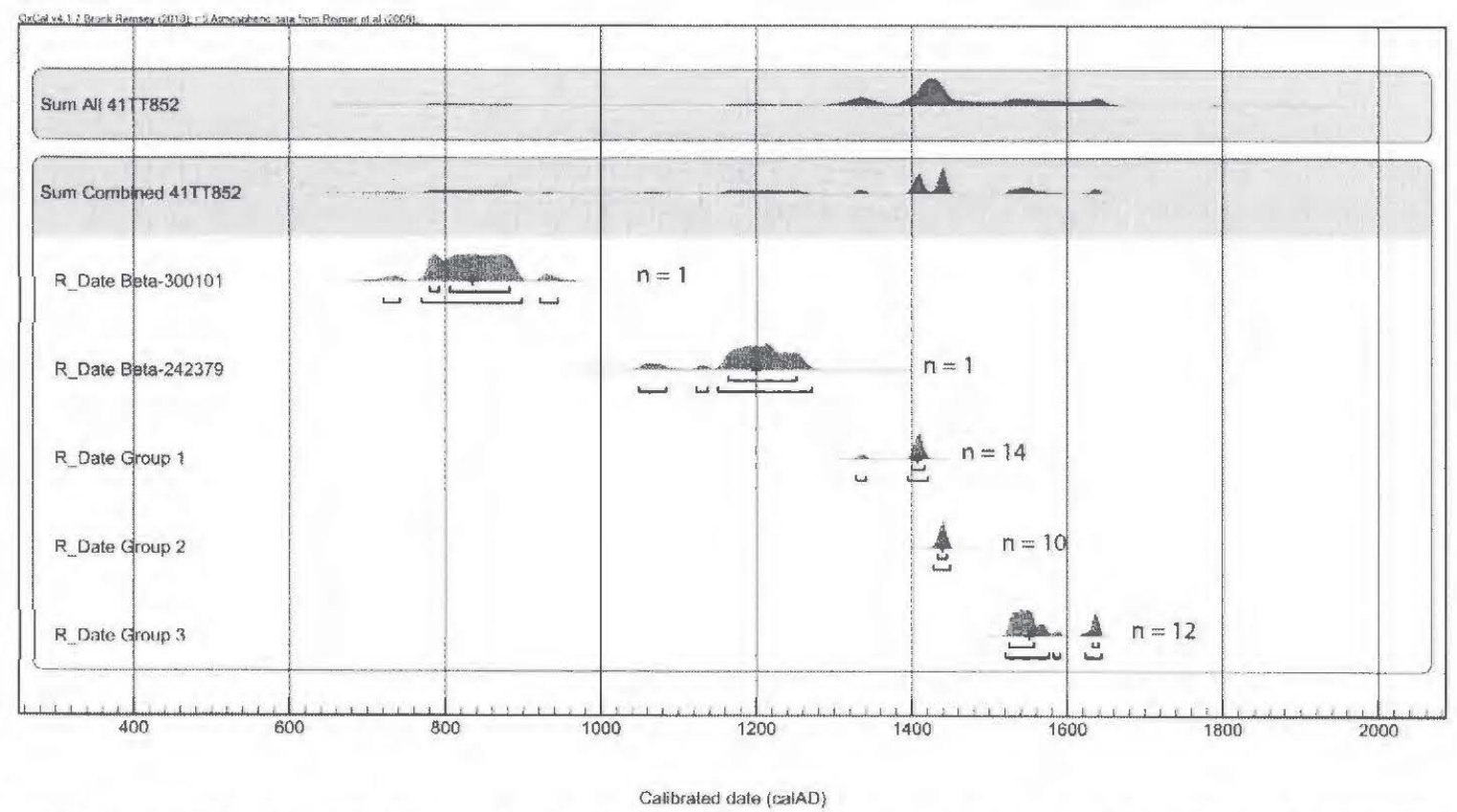

Figure 19. All and combined summed probability distributions for Caddo period dates from the William A. Ford site (41TT852) with $1 \sigma$ and $2 \sigma$ ranges, median ages, and number of samples. 


\section{James E. Richey (4ITT853)}

The Caddo period ${ }^{14} \mathrm{C}$ dates from the James E. Richey site $(\mathrm{n}=20)$ were combined into two groups (Figure 20). Group 1 consists of Beta-300114, Beta-242383, Beta-300111, and Beta-305106. Group 2 consists of Beta-305107, Beta-242384, Beta-242382, Beta-300116, Beta-242390, Beta-300110, Beta-300107, Beta-242385, Beta-305111, Beta-300109, Beta-300117, Beta-242388, Beta-300112, Beta-300113, and Beta300115. A single, and much earlier, date (Beta-305110) was unable to be combined with the two groups.

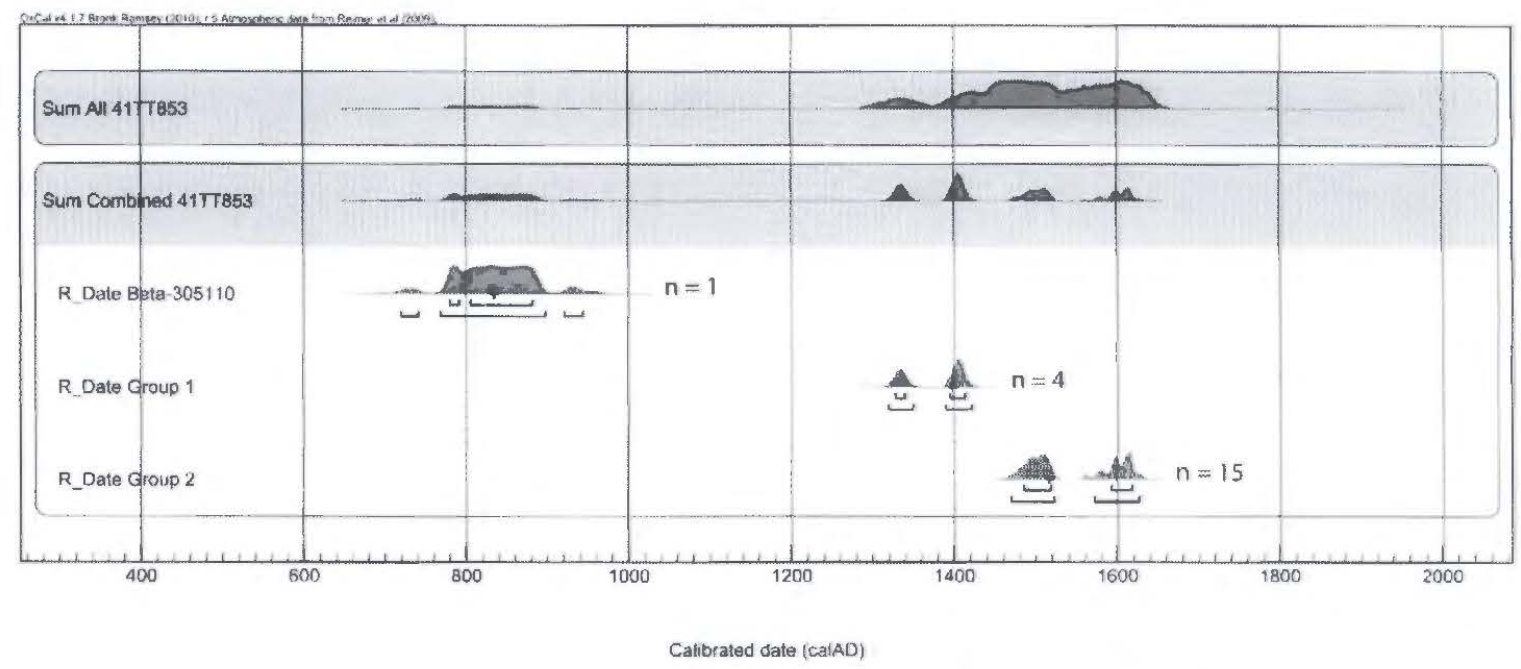

Figure 20. All and combined summed probability distributions for Caddo period dates from the James E. Richey site (41TT853) with $1 \sigma$ and $2 \sigma$ ranges, median ages, and number of samples.

\section{Rookery Ridge (4IUR133)}

The Caddo period ${ }^{14} \mathrm{C}$ dates from the Rookery Ridge site $(\mathrm{n}=11)$ were able to be combined into two groups (Figure 21). Group 1 consists of Beta-132013, Beta-117744, Tx-7989, and Beta-117741. Group 2 consists of Beta-132011, Beta-117740, Beta-132014, Beta-90534, Beta-117742, and Beta-132012.

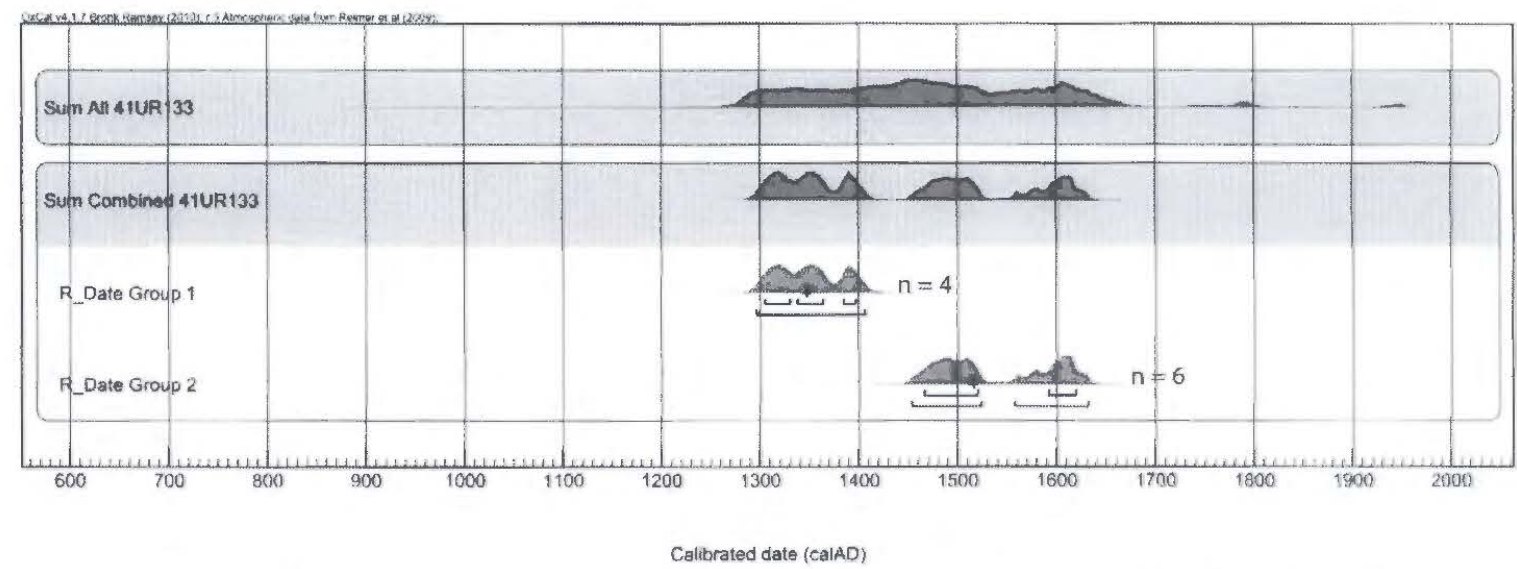

Figure 21. All and combined summed probability distributions for Caddo period dates from the Rookery Ridge site (4IUR133) with $1 \sigma$ and $2 \sigma$ ranges, median ages, and number of samples. 


\section{RESULTS}

Through the use of OxCal's R_Combine process, the number of ${ }^{14} \mathrm{C}$ dates from Caddo sites in East Texas was reduced from 889 with a standard deviation of 58 to 407 with a standard deviation of 53 , reducing probability bias from sites with large numbers of ${ }^{14} \mathrm{C}$ dates, and providing a more accurate representation for the temporal character of sites with $\geq 10{ }^{14} \mathrm{C}$ dates. Subsequent to date combination, the combined ${ }^{14} \mathrm{C}$ assays replaced those assays used to create them, and were then joined with the remaining assays from sites with $<10$ ${ }^{14} \mathrm{C}$ dates, and the summed probability distributions for the Caddo period were updated (Figure 22).

Efforts to analyze the temporal nature of Caddo occupations across the East Texas landscape include assumptions that (1) ${ }^{14} \mathrm{C}$ dates that can be combined via OxCal X-test represent a single occupational episode, (2) the summed probability distribution for archaeological sites with $\geq 10^{14} \mathrm{C}$ assays illustrates the discrete or diffuse nature of occupational episodes, and (3) median dates represent the age of highest probability within each date range. Subsequent to data combination, the Caddo sample consists of 49 dates from the Red River basin (RRB), 71 dates from the Sulphur River basin (SRB), 89 dates from the Cypress Creek basin (CCB), 92 dates from the Sabine River basin (SaRB), and 106 dates from the Neches River basin (NRB). The shift in sample size (Figure 23) illustrates the reduction in the number of ${ }^{14} \mathrm{C}$ dates from each of the four river basins where sites were found to have $\geq 10$ assays. When rounded to the nearest year, Caddo period sites have the oldest median age in the Sulphur River basin (A.D. 1199), followed by the Red River basin (A.D. 1200), Neches River basin (A.D. 1286), Sabine River basin (A.D. 1304), and the Cypress Creek River basin (A.D. 1352).

Summed probability distributions from these 19 sites are subdivided by river basin, making it possible to view their impact upon the Caddo sample from each of the major drainages, and clarifying the source of the numerous increases and decreases in probability within the periods (Figure 24). Through a reduction in probability bias within the sample via date combination, the temporal character of these sites can be contrasted to one another in a more accurate manner, and the average number of ${ }^{14} \mathrm{C}$ dates in the Caddo sample decreases from 5.887 to 2.695 . This helps to identify archaeologically contemporary sites within the sample, while also clarifying the discrete or diffuse nature of occupational episodes at each.

\section{DISCUSSION}

Although survey bias does exist, it is evident that the most extensive Caddo occupation of the East Texas landscape occurred during the Middle Caddo period. This period is marked by increased variability in ceramic style and motifs that coincide with economic changes and shifts in settlements patterns (Perttula and Black 2003), and can be seen throughout all major river basins in the region.

From A.D. 800-1680, the East Texas Caddo resided in the Pineywoods and Post Oak Savanna regions. Evidence from pollen cores in Big Sandy Creek appear to correlate with a higher drought frequency and increased fire magnitude during the Formative Caddo period, and other periods may have had a lower drought frequency and increasingly infrequent fire magnitude (see Albert 2007:Table 7). While paleoenvironmental reconstruction is difficult due to the absence of fossil pollen in the majority of East Texas soils during the late Quaternary (Bryant and Holloway 1985; Weinstein and Bryant 1993), synthesizing the numerous ${ }^{14} \mathrm{C}$

dates from corn with the results from stable isotope analyses could help to clarify much with regard to the temporal dynamics and the regional exploitation of this important food resource. 


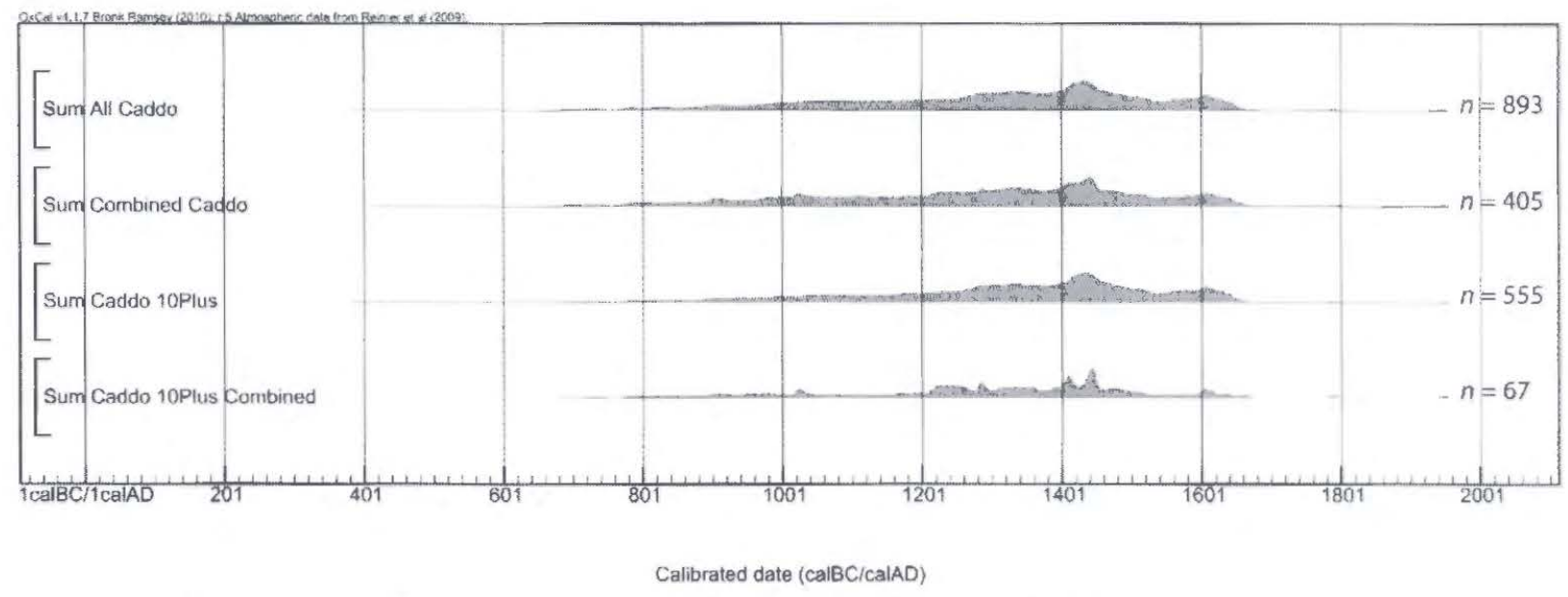

Figure 22. Summed probability distributions illustrating the effect of the date combination process upon the entirety of the Caddo period, and upon those sites with $\geq 10{ }^{14} \mathrm{C}$ samples.

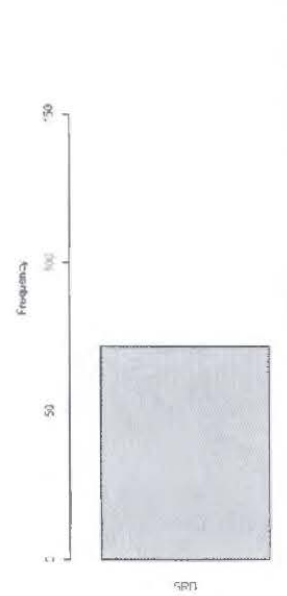

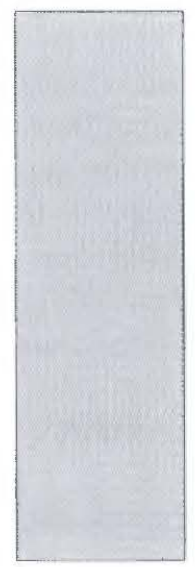

$\operatorname{ccs}$

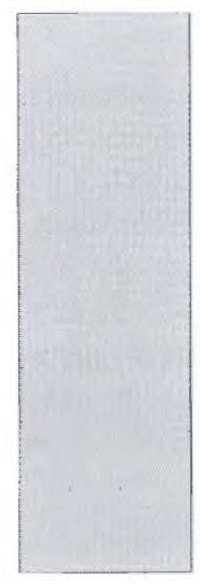

CCB

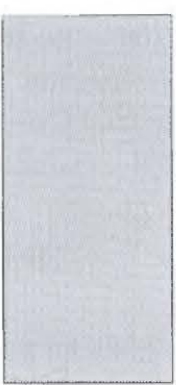

Sure

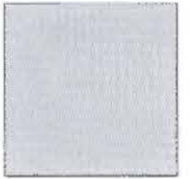

solt

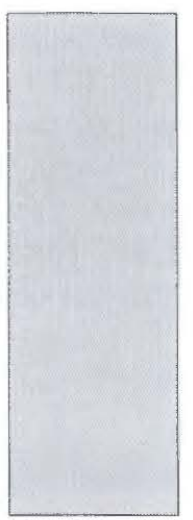

Ner

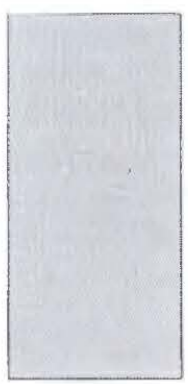

I.99

Figure 23. Frequency of samples by river basin for sites with $\geq 10{ }^{14} \mathrm{C}$ assays before (top) and after (bottom) date combination. 


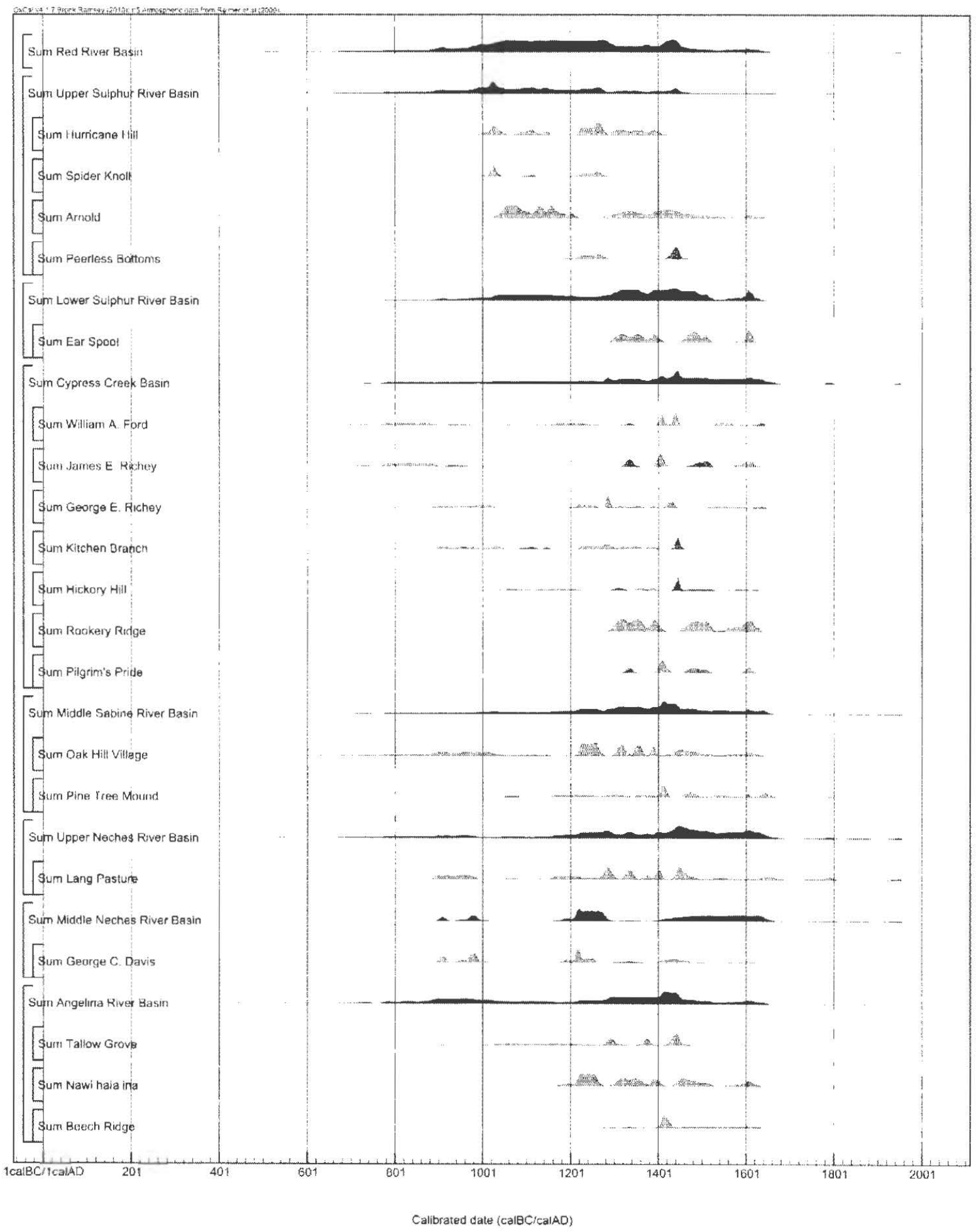

Figure 24. Summed probability distributions from the 19 sites contrasted with the entirety of the sample from each river basin. 


\section{CONCLUSIONS}

The date combination process, when paired with summed probability distributions. allows for the establishment of more accurate and precise temporal ranges for Caddo archaeological sites in Fast Texas; in this case, 19 important sites with $\geq 10{ }^{14} \mathrm{C}$ samples. Within the context of synthetic research concerning all available Caddo radiocarbon dates, this method can be used to explore the temporal range of sites, and then their combination can be a means of highlighting the temporal trends within the Caddo archacological tradition (ca. A.D. 800-1680). Taken together, the analysis of Caddo radiocarbon dates can help to identify and/or clarify features or events at multiple sites that appear to be archaeologically contemporary.

\section{REFERFNCES CITED}

Albert, B. M.

2007 Climate, Fire, and Land-Use History in the Oak-Pine-Hickory Forests of Northeast Texas during the Past 3500 Years. Castanea 72(2):82-91.

Bronk Ramsey, C.

2008 Radiocarbon Dating: Revolutions in Understanding. Archaeometry 50(2):249-275.

2013 OxCal 4.1.7.Electronic resource, https://c14.arch.ox.ac.uk/login/login.php?Location=/oxcal/OxCal. html, accessed July 1, 2013.

Bryant. V. M. and R. G. Holloway

1985 A Late Quaternary Paleoenvironmental Record of Texas: An Overview of the Pollen Evidence. In, Pollen Records of Late Quaternary North American Sediments, edited by V. M. Bryant and R. G. Holloway. pp. 39-70. American Association of Stratigraphic Palynologists Foundation, Dallas.

Clark, R. M.

1975 A Calibration Curve for Radiocarbon Dates. Antiquity 49(196):251-266.

Michczynska, D. J. and A. Pazdur

2004 Shape Analysis of Cumulative Probability Density Function of Radiocarbon Dates Set in the Study of Climate Change in the Late Glacial and Holocene. Radiocarbon 46(2):733-744.

Perttula, T. K. and S. Black

2003 Middle Caddo, A.D. 1200-1400. Electronic resource, http://www.texasbeyondhistory.net/tejas/ancestors/middle.html, accessed July l, 2013.

Perttula T. K. and R. Z. Selden, Jr.

2011 East Texas Radiocarbon Database. Electronic resource, http://counciloftexasarcheologists.org/'page_ id $=27$, accessed July 1, 2013

Reimer, P. J., M. G. L. Baillie, E. Bard, A. Bayliss, J. W. Beck, P. G. Blackwell, C. Bronk Ramsey, C. E.

Buck, G. S. Burr, R. L. Edwards, M. Friedrich, P. M. Grootes, T. P. Guilderson, I. Hajdas, T. J. Heaton, A.

G. Hogg, K. A. Hughen, K. F. Kaiser, B. Kromer, F. G. McCormac, S. W. Manning, R. W. Reimer, D. A.

Richards, J. R. Southon, S. Talamo, C. S. M. Turney, J. van der Plicht, and C. E.Weyhenmeyer

2009 IntCal09 and Marine09 radiocarbon age calibration curves, 0-50,000 years cal BP. Radiocarhon 51(4):1111-1150.

Selden Jr., R. Z.

2012 Modeling Regional Radiocarbon Trends: A Case Study from the East Texas Woodland Period. Radiocarhon 54(2):1-27.

2013 Consilience: Radiocarbon, Instrumental Neutron Activation Analysis and Litigation in the Ancestral Caddo Region. Ph.D. dissertation, Department of Anthropology, Texas A\&M University, College Station. 
Selden Jr., R. Z. and T. K. Perttula

2013 Radiocarbon Trends and the East Texas Caddo Tradition (ca. A.D. 800-1680). Southeastern Archaeology 32(1):85-96.

Sirkin, R. M.

2006 Statistics for the Social Sciences. Sage, Thousand Oaks, California.

Story, D. A.

1990 Radiocarbon Assays. In The Archeology and Bioarcheology of the Gulf Coastal Plain, by D. A. Story, J. A. Guy, B. A. Burnett, M. D. Freeman, J. C. Rose, D. G. Steele, B. W. Olive and K. J. Reinhard, pp. 658-735. 2 Vols. Research Series No. 38. Arkansas Archeological Survey, Fayetteville.

Stuiver, M. and P. J. Reimer

1993 CALIB User's Guide Rev 3.0.3A for Macintosh computers. Quaternary Research Center, University of Washington, Seattle.

Ward, G. K. and S. R. Wilson

1978 Procedures for Comparing and Combining Radiocarbon Age Determinations: A Critique. Archaeometry 20(1):19-31.

Weinstein, E. and V. M. Bryant Jr.

1993 Pollen Analysis of Core Sediments from the Karnack Quad, Texas and Old Soda Lake Bed, Louisiana. In Geomorphic Investigation of Shreveport to Dangerfield Navigation Project, edited by P. A. Albertson and J. B. Dunbar, Appendix C. U.S. Army Corps of Engineers Technical Report GL-93-91, Vicksburg, Mississippi.

Williams, A. N.

2012 The Use of Summed Radiocarbon Probability Distributions in Archaeology: A Review of Methods. Journal of Archaeological Science 39(3):578-589. 